\title{
TRADE REFORMS AND WELFARE: AN EX-POST DECOMPOSITION OF INCOME IN VIETNAM
}

\author{
Aylin Isik-Dikmelik ${ }^{*}$
}

\begin{abstract}
This paper analyzes the impact of trade reforms on household welfare. In particular, the importance of each of the links that together constitute the impact is studied using data from the Vietnamese experience in the 1990s. The implementation of trade reforms in the 1990s, most noteworthy of which was the liberalization of rice, resulted in a substantial improvement in welfare as evidenced by the drastic decline in poverty. Using analytical and empirical methods, we examine the role of each channel (direct vs. indirect) in this improvement for different groups of households. Results indicate that the growth has been broad based and pro-poor. Poorer households experienced more growth for each and every group analyzed. Moreover, contrary to the standard literature, net buyer households had more growth compared to net sellers, emphasizing the importance of the indirect links. Decomposition of the growth illustrates that for rural households, both the direct effects and the multiplier effect drive growth while the multiplier effect was key in urban areas. The importance of the secondary effects underscores the need for a broader model to estimate the impact of trade reforms fully.
\end{abstract}

World Bank Policy Research Working Paper 4049, November 2006

The Policy Research Working Paper Series disseminates the findings of work in progress to encourage the exchange of ideas about development issues. An objective of the series is to get the findings out quickly, even if the presentations are less than fully polished. The papers carry the names of the authors and should be cited accordingly. The findings, interpretations, and conclusions expressed in this paper are entirely those of the authors. They do not necessarily represent the view of the World Bank, its Executive Directors, or the countries they represent. Policy Research Working Papers are available online at http://econ.worldbank.org.

\footnotetext{
* Development Economics Research Group, World Bank. Email: aisikdikmelik@worldbank.org. I would like to thank Ataman Aksoy, Alessandro Nicita, and Marcelo Olarreaga and an anonymous referee for helpful comments.
} 


\section{INTRODUCTION}

Analysis of the impact of trade liberalization on the household welfare generally falls under one of the two main approaches; ex-ante studies, where change in prices due to a proposed trade liberalization is simulated and then in turn is used to estimate the change in household welfare, and ex-post econometric studies, where the data before and after the change in prices are used to estimate changes in household welfare ${ }^{1}$. Some examples of the former are Ravallion (1990) and Minot \& Goletti (2000). Dercon (2005), Nicita (2004), and Porto (2003) are among the few studies that employ the latter methodology ${ }^{2}$. Typically, the main impact of trade reforms on household welfare is through the changes in prices. The standard literature result ${ }^{3}$ is that net sellers of the good will benefit while net buyers will suffer in response to an increase in the price ${ }^{4}$. However, as Porto (2005) shows, the net buyer approach might be misleading, as it's only taking into account the static response. In fact, the quantity response (both from the consumer side, i.e. substitution, and producer side i.e. increasing production) as well as other indirect links are likely to play a big role. This paper investigates the importance of the various links in household's dynamic response (hence welfare) using Vietnam data before and after major trade reforms. Although, it is hard to attribute all the changes in household welfare to trade reforms, as Litchfield et al. (2003), by constructing a counterfactual without the reforms, find the liberalization was a crucial component of the decline in poverty in Vietnam.

In general, poor households spend a majority of their income on food. The expected effect of an increase in food prices on the urban poor, who are net buyers of food, will be negative. For rural poor the results are ambiguous due to two offsetting forces. In rural areas majority of the households (including the poor) are also producers of food, hence the net effect will depend on whether the household is ultimately a net

\footnotetext{
${ }^{1}$ For both of these approaches, both impact analysis and analysis allowing for behavioral responses have been used in the literature.

${ }^{2}$ Reimer (2002) provides a good survey of the literature.

${ }^{3}$ For instance, Mellor (1978) (examining the effect of changing relative food prices on consumers, producers, employment, and agricultural production using data from India as examples), and Barrett \& Dorosh (1996) (analyzing a change in the price of rice in Madagascar) observe that higher food prices will benefit the net food sellers and will have a negative impact on net food buyers.

${ }^{4}$ Underlying this result is the fact that in most developing countries, (particularly in rural areas) households are both producers and consumers of some of the commodities, especially major food crops.
} 
buyer (subsistence farmer) or a net seller (market integrated farmer). Clearly the effect on poverty will be determined by the composition of net food buyers and sellers in rural and urban areas. Barrett \& Dorosh (1996) state that majority of the small farmers are net food buyers and hence will be adversely affected from an increase in food prices.

Deaton (1989), examining the effect of a hypothetical change in rice prices on the real income distribution in Thailand using non parametric techniques, finds that higher rice prices will benefit all rural households (the extent of which depends on the region), especially the middle-income ones. A similar study by Budd (1993) for Cote d'Ivoire show that impacts will be different for various regions and the magnitude will be relatively small, concluding that rural poor will not be affected much. Barrett \& Dorosh (1996) extend the methodology and examine the effect of a change in rice prices on household welfare in Madagascar. They find that a good portion of the farmers are net rice buyers and will likely suffer from increased rice prices (based on first order effects). As they also mention, this contradictory result (to the previous two similar studies) may be due to the fact that rice is the major staple with very high budget shares, and also that Madagascar is a low income country unlike the wealthier Thailand.

Vietnam has experienced a drastic decline in poverty in the last decade. During this time it also took big unilateral steps in trade liberalization and is now one of the most open economies in Southeast Asia. The reforms for liberalization started in the late 1980's with the "doi moi” reforms. The aim of "doi moi" was to slowly change Vietnam's economy into a market economy. Domestic and external trade policy reforms have increased Vietnam's involvement with the world ${ }^{5}$. One of the most important reforms in trade policy was the liberalization of trade in rice. Rice is the major staple in Vietnam; approximately $80 \%$ of the households cultivate rice, $50 \%$ of which is for subsistence. Vietnam is one of the major exporters of rice in the world accounting for 9$17 \%$ of world rice exports. In the last decade, it has been the second largest exporter (by volume) of rice (Minot and Goletti, 2000). This paper aims to analyze the impact of the trade reforms (the most attention grabbing of which is the rice liberalization) and consequently the increase in price of rice on the welfare of different groups of households (i.e. net rice buyers, sellers). Panel data is used in providing the income growth for each

\footnotetext{
${ }^{5}$ The land titling reform and liberalization of the fertilizer market are such examples. See Niimi et al (2003) for a detailed description of "doi moi" reforms.
} 
group and the decomposition of this growth by income sources demonstrates the importance of different links. In addition, we empirically study the potential determinants of growth. Given the importance of rice in Vietnam's trade and agriculture, and also in consumption, the liberalization of rice in Vietnam in the 90's constitute an excellent case to study the effect of trade policy reform, and the links through which it may operate on households.

There are few studies that document the experience of Vietnam in the 1990s. Glewwe et al (2000) examined how poverty changed and the effect of Vietnam's economic success on poverty. They used a multinomial logit model to estimate the movements in and out of poverty from 1993 to 1998 and the determinants of these movements in addition to providing descriptive analysis of the poverty profile. Niimi et al. (2003) build on the framework of Glewwe et al. (2000) and focus on the trade effects of for both urban and rural populations. They also introduce, and test a conceptual framework that links trade liberalization and extreme poverty. Benjamin \& Brandt (2004) provide a description of the changes occurred in Vietnam between the two surveys, and analyze the effect of these changes on the distribution of welfare.

Our approach is mostly different from these studies. The effect of the reforms on the welfare of different groups of households is analyzed to trace the validity of earlier theoretical results. We document the characteristics of different groups of households and the switch between them in addition to examining how they fared. We follow Winters (2002) in analyzing the link between trade liberalization and prices and also tracking the effects on other earnings (e.g. returns to production factors). Income is used as the measure of welfare to illustrate the factor income price and employment link more explicitly. Sources of income offer a better idea of how a given household will be affected from trade liberalization compared to patterns of expenditure. The expenditure patterns are likely to be more similar among households with similar total expenditures while income sources are the differentiating factor. Van de Walle \& Cratty (2003) note that a household's sources of income noticeably affect their standard of living. Decomposition of the income growth (to its income sources) for each group is studied to understand the importance of various links in household welfare. Multivariate regression analysis is performed to examine the factors that contribute to the change in welfare. 
The results show that the trade reforms benefited all households. The extent of this benefit differs depending on where households live (urban-rural, regions) and whether they are net rice buyers or sellers and other characteristics. The distribution of the gains is such that poorer households experienced the most gain no matter which category of households is analyzed. Thus the growth has been pro-poor, which is also evidenced by the drastic decline in poverty rates during this period.

The decomposition of the income growth illustrates the importance of the various links through which households benefit. The direct effect, through change in rice price and production (hence income from rice), is most important for net seller households and households that lived in South. The indirect effect, the effect on other earnings especially non-farm business income and wages (non agricultural), proves to be a significant part of the growth for all households. The labor market link is not significant for rural households as documented by the small (mostly negative) contributions of agricultural wages to growth. Almost all of the rural households (92\%) had rights to some land during both surveys. This fact combined with the low shares of agricultural wages in income indicates that agricultural labor is not widespread in Vietnam. Empirical analysis confirms our initial finding that regions experience different growth rates. In addition, rural households that specialize in food crop production experience higher growths. Similarly, rural households who get more of their income in 1998 (compared to 1993) from non-farm business had more growth. We also find that households which switched from being a net buyer to a net seller are associated with more growth compared to those that switched from net seller to buyer.

The rest of the paper is organized as follows. The next section presents an overview of the Vietnamese economy, providing descriptive statistics and characteristics of households. Section 3 provides the theoretical background and the analytical approach. Section 4 presents the decomposition of the growth by sources of income and the empirical determinants of growth. Section 5 concludes. 


\section{ECONOMY \& HOUSEHOLD CHARACTERISTICS}

Vietnam is mostly a rural country; $80 \%$ of the population resides in rural areas. Moreover, the incidence of poverty is higher in rural (45.2\%) compared to urban areas $(10-15 \%)$ and $90 \%$ of the poor live in rural areas ${ }^{6}$. Agriculture is still very prominent in Vietnam. The population in rural areas is concentrated in the main rice growing deltas: Red River Delta and Mekong Delta. Geographically Vietnam can be divided into two main regions; North and South, where South includes the Mekong Delta and North includes the Red River Delta. These two regions show dramatic differences in production and welfare.

The main staple crop is rice which is cultivated by $80 \%$ of the households. Approximately 65\% of the cultivated area is under rice. Furthermore, Vietnam is one of the three major rice exporters in the world. Rice constitutes a major part of (around 60\%) of the caloric intake for all the households in Vietnam (Minot and Goletti, 2000). Urban households consume less rice per capita than the rural ones. In addition, around 95\% (91\%) of the urban households are net rice buyers (consume more rice than they produce $^{7}$ ). On the other hand, only 49\% (53\%) of the rural households are net buyers in 1993 (in 1998).

Trade reforms were a major part of the "doi moi” reforms in Vietnam. A series of reforms including (but not limited to) replacement of quantitative barriers with tariffs were implemented in the $90 \mathrm{~s}^{8}$. Among these reforms the liberalization of rice was central due to the importance of rice in Vietnam. This liberalization had two components: domestic and international. In the international part, Vietnam liberalized the export quota on rice until it was no longer binding in the first part of $1997^{9}$. Complementing this liberalization was the lifting of internal trade restrictions of rice in 1997. Before this domestic reform, the flow of rice from South (where more rice is produced and there is a surplus) to North was restricted to encourage self sufficiency in each region. The internal

\footnotetext{
${ }^{6}$ World Bank (1999).

${ }^{7}$ A detailed description of net buyer-seller household is provided in the next section.

${ }^{8}$ See Niimi et al (2003) for a detailed description of the reforms.

${ }^{9}$ The export quota on rice was abolished in 2001. However, the liberalization in 1997 was very effective as it practically resulted in the quota being redundant. In fact, Vietnam has switched from being a net importer of rice in 1992 to being the second largest exporter (by volume) of rice in 1998 (Litchfield, McCulloh \& Winters (2003).
} 
trade ban coupled with the binding export quota caused low prices of rice in the South and high prices in the North. The increase in export quota and the lifting of internal restrictions has lead to increased rice prices (in real terms) everywhere but proportionally more in the South (Benjamin \& Brandt, 2004; Niimi et al, 2003; Seshan, 2005).

The unit prices in the household data also confirm this. The prices in Vietnam have changed substantially between 1993 and 1998. The general inflation rate was 45.6\% (which corresponds to a yearly inflation rate of 7.8\%). The increase in nominal rice price has been more than the inflation rate in all regions for the sales unit price and almost all regions for the production unit price (Table 1) pointing to an increase in real rice prices at the household level.

\section{Table 1. Change in Producer Rice Prices from 1993-1998, by Region.}

\begin{tabular}{lcc}
\multicolumn{1}{c}{ Rice price } & Increase in Sales unit prices & Increase in Production unit prices \\
\hline Northern Uplands & $57 \%$ & $43 \%$ \\
Red River Delta & $62 \%$ & $35 \%$ \\
North Central Coast & $72 \%$ & $52 \%$ \\
South Central Coast & $98 \%$ & $56 \%$ \\
Central Highlands & $130 \%$ & $86 \%$ \\
South East & $62 \%$ & $54 \%$ \\
Mekong Delta & $65 \%$ & $69 \%$ \\
Total & $67 \%$ & $49 \%$ \\
\hline
\end{tabular}

Source: Author's own calculations using VNLSS 93 and 98 . The percentage change in the mean unit price of one kilogram of rice: from sales and production values and quantities respectively.

\subsection{Data}

Our analysis is based on the panel data from Vietnam Living Standards Survey (VNLSS) for 1992/1993 and 1997/1998. This is a national household level survey with detailed information of household activities (i.e. agriculture, non-farm enterprise, etc.), in addition to the general characteristics (health, education etc.). It also includes a community survey where information about rice prices and locational characteristics are collected. The first round of VNLSS was conducted from September 1992 to October $1993^{10}$. It includes 4800 households with a self-weighted sample design, and two strata: urban and rural. In the second round of VNLSS all the initial households were sought after and some 1200 additional households for interview, for a total of 6000 households.

\footnotetext{
${ }^{10}$ For clarity purposes we'll refer to this as VNLSS 1993, and the second round as VNLSS 1998.
} 
Of the 4800 households 4305 (around 90\%) of them could be interviewed in the second round and it is this panel of households that we use in our analysis ${ }^{11}$.

\section{Table 2. Descriptive Statistics}

\begin{tabular}{|c|c|c|c|c|c|c|}
\hline & \multicolumn{3}{|c|}{1993} & \multicolumn{3}{|c|}{1998} \\
\hline & Rural & Urban & National & Rural & Urban & National \\
\hline Household size & 5.0 & 5.0 & 5.0 & 4.8 & 4.5 & 4.8 \\
\hline Proportion of male household heads & $78 \%$ & $57 \%$ & $74 \%$ & $77 \%$ & $57 \%$ & $73 \%$ \\
\hline Education of HH Head (years) & 5.3 & 6.8 & 5.6 & 6.5 & 8.3 & 6.9 \\
\hline Age (HH head) & 45.2 & 47.3 & 45.6 & 47.7 & 50.6 & 48.4 \\
\hline Proportion of people living in north & $57.3 \%$ & $41.3 \%$ & $54.3 \%$ & $57.2 \%$ & $43.3 \%$ & $54.3 \%$ \\
\hline Proportion of people who don't own any land & $8.1 \%$ & $75.5 \%$ & $20.8 \%$ & $7.2 \%$ & $73.2 \%$ & $21.1 \%$ \\
\hline Land cultivated (m2) & 5353.0 & 3045.9 & 5137.1 & 7325.4 & 4674.6 & 7131.8 \\
\hline Quantity of Harvested rice (kg) & 2232.0 & 1660.6 & 2213.2 & 2912.7 & 2360.5 & 2885.4 \\
\hline Proportion of net seller of rice & $51.0 \%$ & $5.1 \%$ & $42.4 \%$ & $46.9 \%$ & $8.6 \%$ & $38.9 \%$ \\
\hline Received any technical agricultural advice & $58.1 \%$ & $8.5 \%$ & $48.8 \%$ & $64.1 \%$ & $13.5 \%$ & $53.4 \%$ \\
\hline
\end{tabular}

Source: Author's own calculations using VNLSS 93 and 98.

Table 2 shows some of the basic descriptive statistics of the panel sample for the two years. The household size has decreased from 93 to 98; the decline was slightly larger in urban areas. Cultivated land has increased by approximately 40\%. Rice production has on average increased by $30 \%$. After the reforms in 1988, which moved away from collectives and considered households as the unit of economic activity, the government started titling the land to households. Although usable land is a small percentage of available land in Vietnam, most of the households have some land. Only 21\% (21\%) of the households do not own any land in 1993 (1998), and the majority of these households are in the urban area. In 1993 (1998), the landless rate in rural areas is only $8 \%$ (7\%) whereas in urban areas it goes up to 75\% (73\%). For both urban and rural areas, more households utilized technical agricultural advice in 1998 compared to 1993.

\subsection{Income and Expenditure Structure}

An important link through which trade liberalization affects household welfare is prices. The change in prices will affect the expenditure of all households and the income of some households (households that produce the affected commodities). Hence, the extent of the effect on welfare will depend on which products are important income

\footnotetext{
${ }^{11}$ Since the original 4800 households were representative of the country, and the panel includes around $90 \%$ of these households, we'll consider the panel as representative and will not deal with the weighting issues. Van de Walle \& Cratty (2003) also contend that panel households are representative of the nation.
} 
sources for poor and which products are consumed extensively. Therefore, before documenting the magnitude of the effect and estimating the determinants, we will first analyze where different groups of households get their income from and on what they spend their income.

Agricultural production is a major source of income in Vietnam. For rural households income from crops constitutes 41\% (40\%) of total income in 1993 (1998), $24 \%$ (23\%) of which is due to rice (Tables A.1 \& A.3). The total income includes own consumption of the crops cultivated (as they are also a source of income that finances part of the consumption), and is a net income measure, that takes into account the expenses associated with farming and other enterprises owned. On average, more than half of the income from crops is due to production used in own consumption, more so for the poorer households (subsistence) ${ }^{12}$. In addition livestock income and wages from agriculture also constitute a major source (22\% on average), especially for the poorest households (28\%). Although the share of agriculture income in total income has remained the same in 1998, the components have changed. On average, the shares of profit from rice and other crops has increased while the share of own consumption has declined. While the decrease in shares may not reflect a decline in the magnitude (as incomes have increased from 1993 to 1998) the increase in shares indicates a higher amount.

For the urban households, the major sources of income are wages and self employment income for both years. However, agriculture income still has a decent share, especially for the poorer (lowest 3-4 deciles) households. Furthermore, only about half of the agricultural income is from own consumption, pointing to the existence of urban households that are involved in agriculture not just for their own consumption (Figure 1). The structure of income has not changed much for urban households, even though the income levels have changed quite a bit. The share of business income increased for the poorest households while share of own consumption declined.

\footnotetext{
12 Detailed sources of income can be found in Annex, Tables A.1-A.4.
} 
Figure 1. Share of Agricultural Income (excluding own consumption) for Urban.

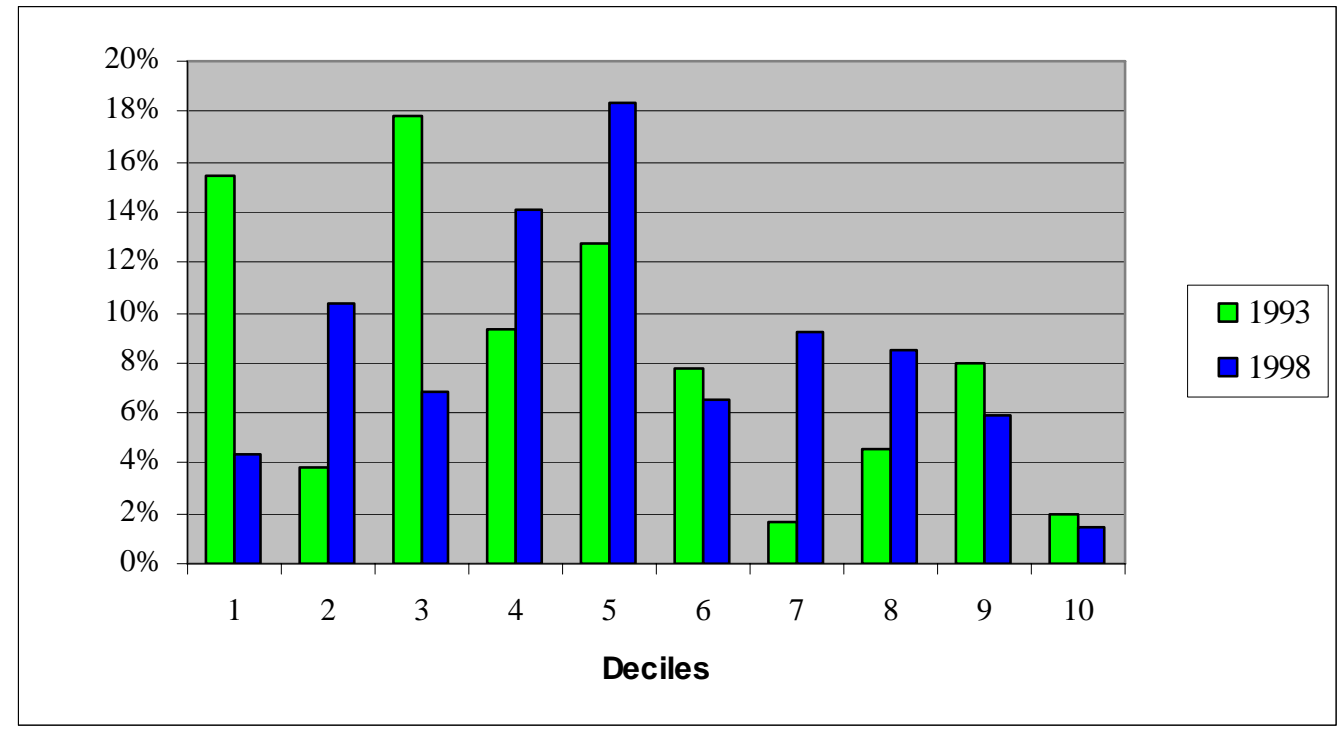

Food items constitute a big share of expenditures for both rural (63\%) and urban (58\%) households in 1998, (67\% and 60\% in 1993 respectively), with more than onethird of it spent on rice. In the poorest decile for rural (urban) households this share goes up to $72 \%$ (67\%) with rice making up 41\% (32\%) of all expenditures (Figure 2). Similarly in 1993, for the poorest decile, the share of food in total expenditure is $75 \%$ in rural and $76 \%$ in urban, with rice expenditure constituting the majority, $43 \%$ and $45 \%$ respectively (Figure 3). Since rice is such a key part of Vietnamese households, any policy that affects the price of rice significantly will have an impact on the welfare of the households. The expenditure on rice is mainly from own consumption among the poor in rural areas, whereas in urban areas share of own consumption is low even among the poor (5\%). Expenditure on education and health makes up a smaller share for poorer households than the richer ones. This difference is more pronounced in rural areas, and it might be due to the fact that the poor are less likely to afford health care, and also less likely to send their children to school. 
Figure 2. Share of Rice Expenditure in Total Expenditure by Deciles, 1998

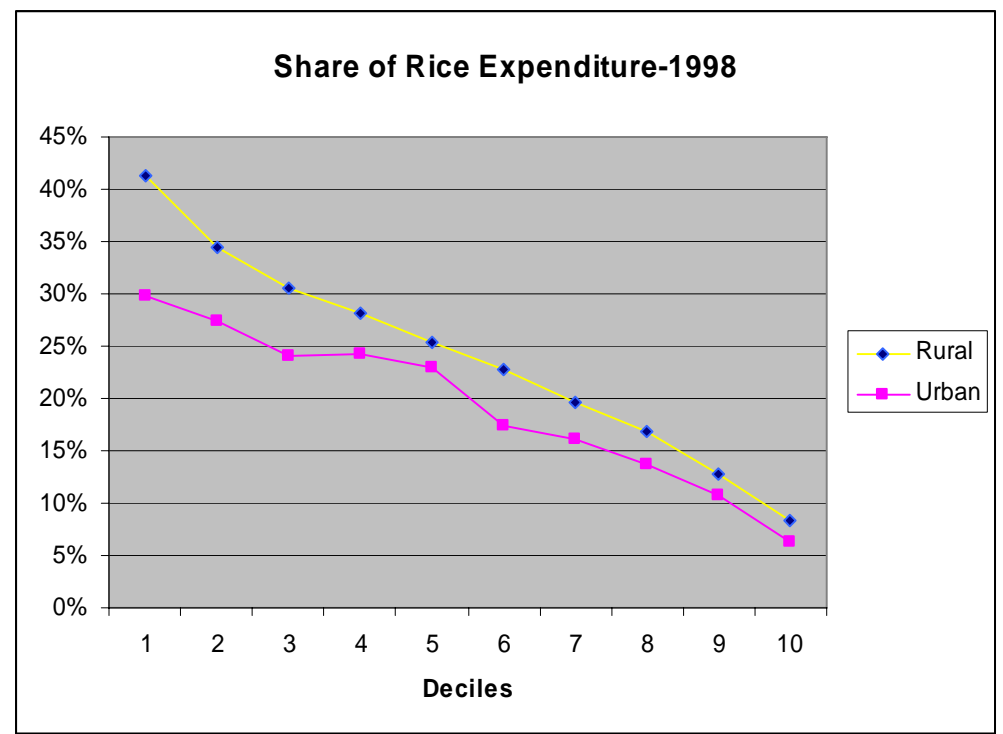

Figure 3. Share of Rice Expenditure in Total Expenditure by Deciles, 1993

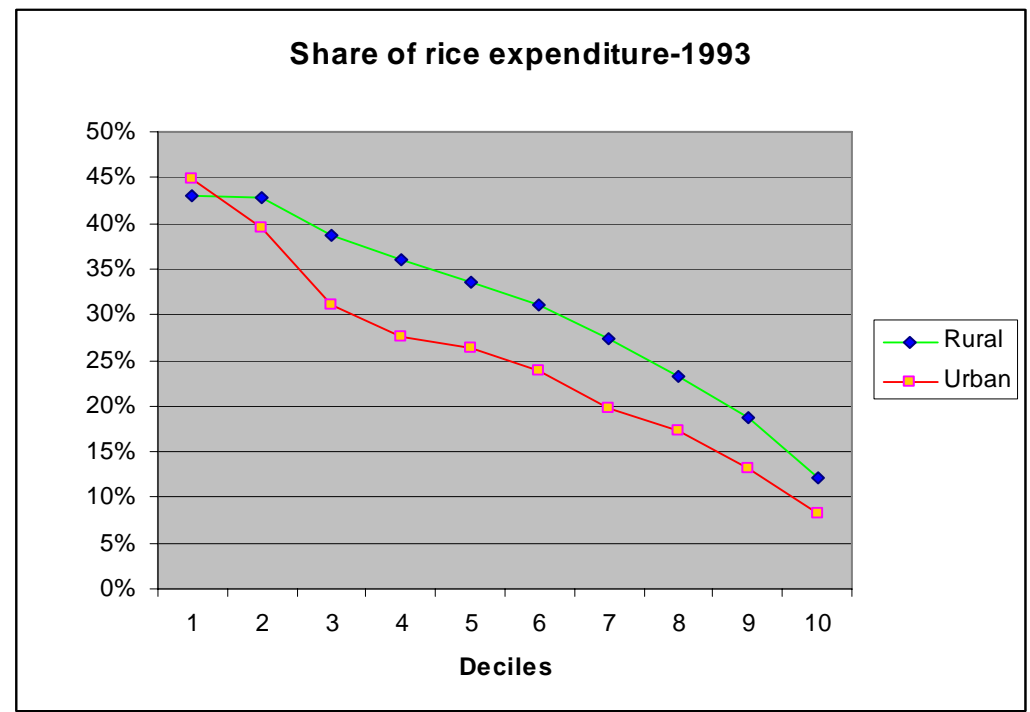

\section{Net seller-net buyer}

Net exposure is cited in the literature as a major factor that determines the impact of a price change on household welfare. Thus, we group the households into net seller- 
buyer categories and outline their characteristics to provide comparability with the studies in the literature.

In the literature the definitions for net seller (buyer) of a commodity range from a positive (negative) net benefit ratio ${ }^{13}$ to the presence (absence) of sales for that commodity. We think that using the presence of sales may not be appropriate, since some households may sell right after harvest, just to buy more of the commodity later in the year, making them net buyers. In terms of no sales, it becomes difficult to distinguish net buyers from subsistence households (consume only as much as they produce). Our definition is similar to the net benefit ratio, without the use of shares. According to our definition a household is a net seller (buyer) of rice if their net sale of rice is positive (negative) where net sales of rice is defined as: value of production of rice - value of own consumption of rice - value of purchased rice. In other words, a household is a net seller (buyer) if it consumes (both in own consumption and purchased) more of the good than it produces. According to this definition, around 95\% of the urban households are net rice buyers whereas only 49\% (54\%) of the rural households are net buyers in 1993 (in 1998).

As Porto (2005) points out the dynamic response of the households makes the definition of net buyer (seller) endogenous, which manifests itself in our data as the switch between net buyers and sellers from 1993 to 1998. The percentage of net buyers of rice has increased $3 \%$ overall in the nation with the increase in rural about $4 \%$ and the decrease in urban some 1\%, from 1993 to 1998 (Table 2). These numbers may seem small but they reflect $12 \%$ of the population (and $29 \%$ of the net sellers in 1993). On the other hand, $9 \%$ of the population (15\% of the net buyers in 1993) switched from being a net buyer to a net seller. It is likely that, some of these switches are households who are close to breaking even (neither net seller nor net buyer, fully subsistence); however, a closer look reveals that there are switchers who were large net buyers initially. A more detailed look at the determinants of net buyer (seller) and the switching is provided in Appendix 2.

\footnotetext{
${ }^{13}$ Deaton (1989) introduced the concept of net benefit ratio which is the share of net sales of a commodity in income. It can be approximated by subtracting the share of the expenditure of commodity in expenditure from share of value of production of the commodity in income.
} 
Table 3. Income of net seller-buyer households

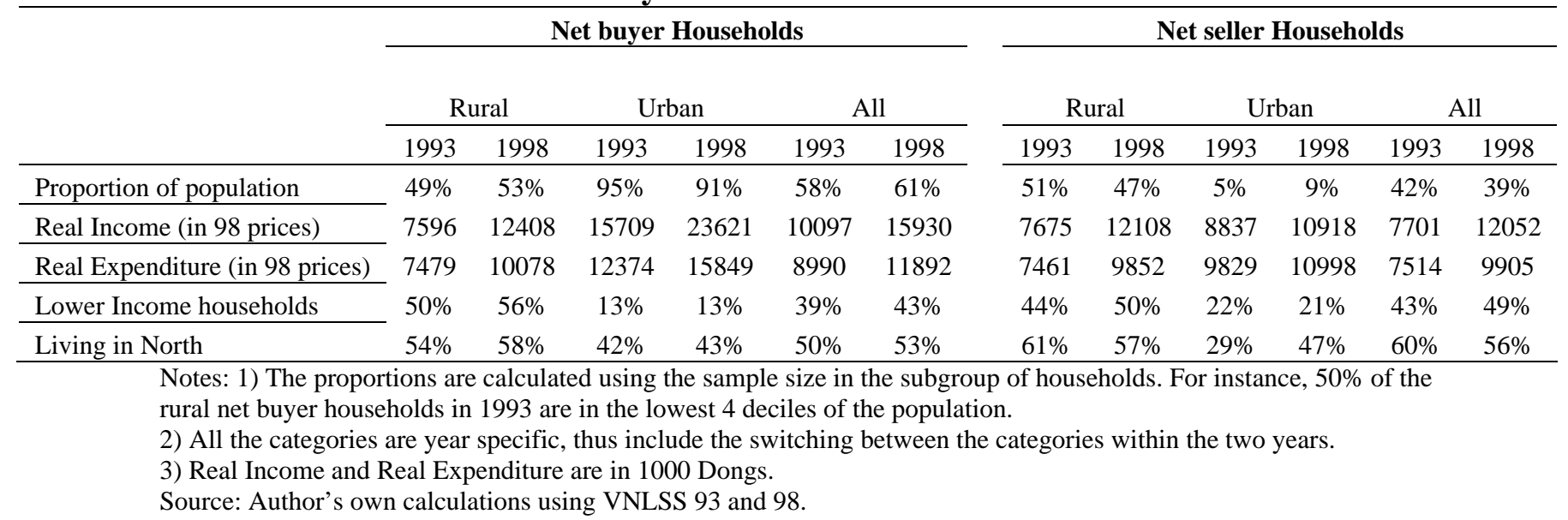

Examining Table 3, we see that on average net-buyers are as wealthy as netseller households. This is an interesting observation since the general conjecture in the literature was that the net sellers of rice are richer than that of their net buyer counterparts. The proportion of lower income households is higher for net buyer households in rural areas, while the reverse is true for urban. However, not all low income households are net buyers. In addition, net buyer households in rural areas are less wealthy than their urban counterparts dispelling the claim that net buyers are urban poor.

In order to determine the degree of vulnerability of net buyers to changes in the price of the staple food ${ }^{14}$, we introduce a measure, namely the intensity of net buying. It is defined as the proportion of the value of net buy to total expenditure where net buy is the net amount of rice bought ${ }^{15}$. The intensity of net rice buying declined from 1993 to 1998 pointing to a decline in the vulnerability of net buyers (Table 4). The negative percentage values represent the share of net-sold rice in total expenditure, and are present since we include the net-buy intensity of all households in our calculation of the mean. If we look at the net buy intensity only among the net buyer households, we find that on average households are moderate net-buyers and their net buying proportion has decreased from 1993 to 1998 . This decline in net buying intensity results may be due to increased expenditure, and/or increased own consumption. Table 5 shows that the

\footnotetext{
${ }^{14}$ Net buyers of food are always cited as being the most vulnerable to food price increases. The degree of vulnerability is thus introduced for only net-buyers.

${ }^{15}$ Net buy of rice $=$ Value of purchased rice + Value of own consumption of rice-Value of production. Put into words, it reflects how much more rice the household is consuming compared to what they produced.
} 
vulnerable group in net buyer households has declined between 1993 and 1998 even though rice prices have increased substantially.

Table 4. Net Buying Behavior of Households

Intensity of net buying (all hholds)

\begin{tabular}{|c|c|c|c|c|c|}
\hline \multicolumn{3}{|c|}{1993} & \multicolumn{3}{|c|}{1998} \\
\hline Rural & Urban & National & Rural & Urban & National \\
\hline$-9.1 \%$ & $14.4 \%$ & $-4.7 \%$ & $-10.2 \%$ & $9.0 \%$ & $-6.1 \%$ \\
\hline $18.0 \%$ & $16.2 \%$ & $17.5 \%$ & $15.5 \%$ & $12.6 \%$ & $14.6 \%$ \\
\hline
\end{tabular}

Source: Author's own calculations using VNLSS 93 and 98.

Table 5. Intensity of Net-Buyers (only net-buyer households)

Marginal (0-10\%)

Medium (10\%-30\%)

Large (>30\%)

Source: Author's own calculations using VNLSS 93 and 98. The numbers represent the distribution of netbuyers across the three intensity categories.

\section{South-North}

There are distinct regional differences between the Northern and Southern part of Vietnam. Since most of the rice farmers live in rural areas and hence the net sellers are mostly in the rural areas, (in urban areas 95\% of the households are net buyers), we will focus our attention on rural households.

Table 6 presents a summary of sources of income for rural households, by their net selling position, and also by the general region (North and South). The difference in income between South and North is still valid for the sub groups of net sellers and buyers. The households in the South are on average richer than their Northern counterparts. On average Northern households has a larger share of agricultural income than that of the South (for both years). However, a closer look into the detailed sources of income reveals that the agricultural income in North is mainly due to own consumption and livestock income. Hence, we can deduce that on average rural northern households are generally subsistence households with respect to crops; while in the South they are mostly rice farmers and cash crop producers (higher share among net-buyers). 
Table 6. Sources of Income for rural, net buyer- seller households, by North South

\begin{tabular}{lcccccccc}
\hline & \multicolumn{4}{c}{ South } & \multicolumn{4}{c}{ North } \\
\cline { 2 - 9 } & \multicolumn{3}{c}{ Net Buyer Rice } & \multicolumn{2}{c}{ Net Seller Rice } & \multicolumn{2}{c}{ Net Buyer Rice } & \multicolumn{2}{c}{ Net Seller Rice } \\
& 1993 & 1998 & 1993 & 1998 & 1993 & 1998 & 1993 & 1998 \\
\cline { 2 - 9 } Income from Agriculture & $37 \%$ & $40 \%$ & $50 \%$ & $60 \%$ & $55 \%$ & $56 \%$ & $69 \%$ & $65 \%$ \\
$\quad$ Sales & $20 \%$ & $29 \%$ & $30 \%$ & $42 \%$ & $24 \%$ & $26 \%$ & $32 \%$ & $37 \%$ \\
$\quad$ Own consumption & $17 \%$ & $11 \%$ & $21 \%$ & $18 \%$ & $32 \%$ & $30 \%$ & $37 \%$ & $28 \%$ \\
Business Income & $21 \%$ & $20 \%$ & $10 \%$ & $11 \%$ & $14 \%$ & $13 \%$ & $9 \%$ & $12 \%$ \\
Agricultural wages & $19 \%$ & $14 \%$ & $18 \%$ & $7 \%$ & $4 \%$ & $2 \%$ & $2 \%$ & $1 \%$ \\
Other wages & $11 \%$ & $11 \%$ & $8 \%$ & $8 \%$ & $9 \%$ & $9 \%$ & $6 \%$ & $8 \%$ \\
Other Income & $11 \%$ & $15 \%$ & $14 \%$ & $15 \%$ & $17 \%$ & $20 \%$ & $14 \%$ & $15 \%$ \\
Total Income $^{\text {a }}$ & 8,415 & 16,033 & 9,131 & 14,631 & 6,891 & 9,740 & 6,734 & 10,192 \\
\hline
\end{tabular}

a: Total income is in 1998 prices, and is measured in 1000 dongs.

Source: Author's own calculations using VNLSS 93 and 98.

We also observe a drastic increase in the share of agricultural income for the Southern households from 1993 to 1998 (for both net buyers and sellers). As real income was also rising (which will be discussed in the next section) this increase in share is even more pronounced. It is due to increase in sales (especially rice income but also others) for net seller households, and due to increase in sales (of mainly food crops) coupled with the decline in own consumption for net buyers. In North, net seller households are also specializing as share of sales increases and own consumption of rice has declined. In sum, specialization is taking place where net sellers in South are selling more (and cultivating more) and net buyers are moving away from producing rice even further and cultivating other crops. In addition, shares of business income and non agricultural wages have increased for net seller households in North, which may be an indication of rice sellers moving away from rice and moving onto other sectors.

Rice is a labor intensive commodity. Thus, it is expected that as rice prices increase the wage rate in agriculture and/or employment in agriculture will increase. The implicit assumption underlying the increased employment is the existence of surplus labor in agriculture. However, as Table 6 illustrates, share of agricultural wages decline across the board. Since real incomes have increased, the decline in share may not necessarily reflect a decline in income from agricultural wages. A closer look reveals that for net buyer households in the South the income from agricultural wages has increased in real terms (especially among the lower deciles 1-5). However, for the rest there is a 
decline $^{16}$. Thus, the expected labor link only takes place in the South among net-buyer households. With the increase in cultivation of rice and specialization in the South, agricultural labor demand might have increased leading to net buyers working on other households' farms.

Majority of the rural households have rights to land in Vietnam (92\%). This coupled with the low shares of agricultural wages in income show that agricultural labor is not widespread in Vietnam. Hence, our results illustrate that the expected labor market effect is small and limited to poorer net-buyer households in the South.

\section{THEORETICAL INSIGHTS and METHODOLOGY}

\subsection{Background}

In order to analyze the impact of the effect of a change in price on household welfare generally an agricultural household model (Singh et al 1986), where households are the unit of analysis, is used. In this model the households both produce and consume some of the goods. The effects of a trade policy change on household welfare may be traced through the prices, the impact on household's earnings (through factor markets), and the impact on the public sector (changes in government's revenue) (Winters, 2002). The effect through prices is twofold; the effect on income (direct price effect on income from the commodity) and the effect on the expenditure through the consumption effect. The farm household model indicates that the first-order effect of a change in food prices on household welfare will depend on the net trading position of the household. Deaton (1989) formalized this with the concept of net benefit ratio (NBR), which is a proxy for the net-trading position of the household, to estimate the first order impacts of price changes on household welfare ${ }^{17}$. The net benefit ratio for a commodity is the difference between production ratio (PR; value of production as a proportion of income, or expenditure) and consumption ratio (CR; value of consumption as a proportion of income, or expenditure) of that commodity. It is the proportion of net sales to income or expenditure and is approximated by the difference between income share of the

\footnotetext{
${ }^{16}$ The role of each source of income in the growth of income is analyzed in the decomposition of growth in Section 4.

${ }^{17}$ Well behaved preferences and technology is assumed in this study.
} 
commodity and expenditure share of the commodity. Formally, the net benefit ratio is expressed as (Deaton, 1997):

$$
\mathrm{NB}=\mathrm{PR}-\mathrm{CR}=\frac{p_{i}^{p} q_{i}}{X}-\frac{p_{i}^{c} y_{i}}{X}
$$

where $q_{i}$ is the production and $y_{i}$ is the consumption, $\mathrm{X}$ is the total income and $p_{i}^{p} \&$ $p_{i}^{C}$ are producer and consumer prices respectively.

Thus, the first-order effects which will be dominating in the short-run will be positive for net seller households and will be negative for net buyer households. The second-round effect of prices, which takes into account the production response, is generally estimated by a Taylor expansion of the first-order effect (Nicita, 2004).

To estimate the overall impact, first the response in production (which is ignored in the first-order effects) and the link through the labor (factor) markets should be taken into account ${ }^{18}$. The basic intuition behind the Stolper-Samuelson theorem may be applied to the labor markets. Increase in the price of a commodity increases the demand for (hence returns to) the factor that's used intensively in its production. For instance, increases in prices of labor intensive products will increase wage rate. However, the wages may not change if there is surplus labor (underemployment) thus the effect is more through increased employment than increase in wage rate. In most developing countries there is surplus labor in rural areas, which underscores the importance of the labor market link in estimating the overall impact. In addition, there is another channel that needs to be taken into account, which can be termed as the multiplier effect. As the incomes of the households rise, the demand for services and other non-farm goods increase creating a spill-over effect. This multiplier effect is hard to estimate in a partial equilibrium framework. In the analytical approach we decompose the contribution of each income source to overall income growth to identify the different links discussed. In this decomposition, we observe that the growth in non-farm sources is substantial indicating a significant multiplier effect.

\footnotetext{
${ }^{18}$ See Porto (2005) for an application on Mexico.
} 


\subsection{Decomposition of Income Growth}

Utilizing the panel nature of the data, we first provide the growth in income for different categories of households. We then provide the growth incidence curves to study how the overall growth is distributed across households within a group. The actual changes in each income source for different groups of households are examined next. As the sum of these changes constitutes the growth in real income, we are able to determine the contribution of each source to total income growth. This in turn allows us to examine the evidence and importance of each channel, albeit indirectly, in response to the trade reforms in Vietnam. However, one must be cautious in attributing all the changes to trade reforms. On the other hand, it is established that the reforms played an important role in the growth (and the decline in poverty) experienced in Vietnam between 1993 and 1998 (Litchfield et al., 2003; Seshan 2005).

Analytically, the sources of income are grouped into four main categories: agricultural income, non-farm self employment (business) income, income from wages (agricultural and other), and other income (remittances, pension and etc.). The changes in each source of income (and their role in overall growth) are calculated for the same group of households taking the initial (1993) categories as the base.

Agricultural income includes the livestock income, value of crops produced and consumed at home, and profit from crops. Profit from crops and own consumption of crops can be thought of as capturing the direct price and production effect of a trade policy change. As prices change, the direct effect would be through prices and in the longer term the production would respond, thus manifesting itself in the income from crops.

The factor income link on household earnings may be captured by the agricultural wages, since labor is the only factor supplied for most households, especially in rural areas. Non agricultural wages may represent the labor market link in urban areas. In addition, the multiplier (development) effect may be signified by the contribution of business income and non-agricultural wages. We do not provide direct estimate these links (first and second-round price effects, labor market effect, and the multiplier effect) due to data constraints and thus it is beyond the scope of this paper. However, with the 
categorization of income sources as described above we are able to examine indirect estimates of each link for the Vietnam experience.

\subsection{Empirical Approach}

\section{Income Determinants}

The decomposition of income growth aimed to provide insights into the components of the total income growth. In this section, we take a more formal approach and analyze the determinants of the changes in welfare. In other words, we investigate empirically who gained the most and what characteristics were associated with the growth in welfare. The empirical method we use is a reduced form approach where the relations between various household characteristics and income are examined. Before the determinants of income growth are examined, utilizing the panel nature of our data, we first investigate the microeconomic determinants of household welfare using a fixed effect model ${ }^{19}$. Formally we estimate:

$$
\log y_{h, t}=\mu_{h}+\varphi X_{h, t}+\omega_{h t}
$$

where $\log y_{h, t}$, the dependent variable, is the real household income (logarithm) and independent variables include indicators such as; household head's demographics and education, regional dummies, if the household owns any land or not (for urban), logarithm of land size for rural regression, if the households is a net seller or not, and share of cash crop income as a proxy for the cash crop farmers.

\section{Change in Welfare}

A reduced form approach is adopted to estimate who gained the most and which links are the most important for the effect of liberalization on household welfare ${ }^{20}$. In particular, exploiting the panel nature of our data we use the initial household characteristics as well as the changes in endowments and characteristics as our

\footnotetext{
19 The presence of fixed effects has been confirmed using a Hausman test. Although Hausman test may have been biased due to potential measurement errors, we felt it prudent to adopt the Fixed Effects model. In the Annex we present our results using the Random Effects model as well (Table A.8).

20 The specification is similar to that of Dercon (2005).
} 
independent variables. The dependent variable is the change in household real income (i.e. growth in income). Formally, our specification is as follows:

$\Delta \log y_{h, t}=\alpha+\beta X_{h, 1993}+\delta \Delta X_{h}+\varepsilon_{h, t}$

where $\mathrm{X}$ is the matrix of initial household characteristics (household size, age, education, gender, region, land and etc.) and $\Delta X_{h}$ is the change in endowments and status (change in land, change in shares of different income sources, and etc.). This specification allows us to examine the relation between endowments and the change in welfare, in addition to the relation to returns to certain assets and characteristics. It is similar to a firstdifferenced estimation with the obvious inclusion of level variables in our case. Since we are using a difference model, the time invariant factors are also controlled for. We estimate this model using OLS, which ensures that marginal return coefficients (for the differenced variables) control for unobserved fixed effects. The standard errors are corrected for clustering and survey design (Deaton, 1997) with communes as our clusters to take into account that households in the same commune may not be independent. Clearly, the issue of endogeneity, specifically with respect to the difference variables is a potential problem. The initial characteristics of the households are predetermined, thus any questions about their simultaneity is avoided. For the difference variables, we add each separately and interpret our results cautiously without putting too much weight on the value of coefficients (due to potential inconsistency of the estimates). However, even inconsistent estimates will give us some insight about the association between income growth and the changes in the characteristics.

\section{RESULTS}

\subsection{Growth in Income}

The liberalization of rice in Vietnam has affected the welfare of households substantially. Although there have been other reforms to move to a market economy between 1993 and 1998, the trade reform on rice is the one of the most important. Table 7 presents the effect of reforms by providing percentage changes in real income for 
different groups of households. Since the data used is a panel, the growth in real incomes reflects the growth for the average income of the same households from 1993 to 1998. The different categories presented refer to the households that were in that specific group in 1993. Table 7 illustrates that the income of an average Vietnamese household has increased by 59\% between 1993 and 1998. A look at the sub-categories show that rural households' income increased (63\%) more than their urban counterparts (49\%). Similarly net buyer households experienced a slightly higher increase in their income compared to net seller households. This is in contrast with the standard literature result, which only take into account the direct first round effects. Moreover, contrary to popular view that net-buyer households will lose in response to an increase in prices, when we examine the income changes in net buyer households according to their intensity, we find that large net buyers (for which the amount of net buy is more than $30 \%$ of their total expenditure) experience the highest increase (80\%). Across the regions, North Central Coast and Central Highlands seem to have gained the most at 94\%, and more than double (101\%) respectively. However, these regions are the poorest to begin with which could explain the higher than usual growth rates for income.

Table 7. Changes in Real Income for Different Groups of Households.

\begin{tabular}{|c|c|}
\hline \multirow{2}{*}{$\begin{array}{l}\text { Households } \\
\text { All Vietnam }\end{array}$} & \% Change in real income \\
\hline & $59 \%$ \\
\hline Rural & $63 \%$ \\
\hline Urban & $49 \%$ \\
\hline \multicolumn{2}{|l|}{ Seller-buyer category } \\
\hline Net buyer & $60 \%$ \\
\hline Net seller & $56 \%$ \\
\hline \multicolumn{2}{|l|}{ Net buying intensity } \\
\hline Marginal buyer & $52 \%$ \\
\hline Medium Buyer & $64 \%$ \\
\hline Large Buyer & $80 \%$ \\
\hline \multicolumn{2}{|l|}{ Regions } \\
\hline Northern Uplands & $51 \%$ \\
\hline Red River Delta & $42 \%$ \\
\hline North Central Coast & $94 \%$ \\
\hline South Central Coast & $79 \%$ \\
\hline Central Highlands & $101 \%$ \\
\hline South East & $53 \%$ \\
\hline Mekong Delta & $58 \%$ \\
\hline
\end{tabular}

Source: Author's own calculations using VNLSS 93 and 98. 
The measures of inequality (Gini index and Theil index) for total household income are presented in Table 8. They indicate that the overall inequality in income has not changed much even though all households have experienced income growth. Although the overall inequality does not appear to change much, the difference between urban and rural areas is striking. While the inequality in income slightly declined in rural areas, it increased in urban. Only 11\% of the overall inequality in 1993 was due to ruralurban difference and this proportion decreases to 9\% of the total inequality in 1998 pointing to a closing of the gap. Table 8 also presents the inequality for the 7 regions. Three of the main regions (North Central Coast, South East, and Mekong Delta) experienced slight declines in inequality, while rest experienced increases; with Red River Delta and Central Highlands experiencing drastic ones. Between group inequality has stayed proportionately the same, thus the regional gap stayed the same.

\section{Table 8. Inequality Measures for Income}

\begin{tabular}{lcccc} 
& \multicolumn{3}{c}{ Income } & Gini \\
\cline { 2 - 5 } & \multicolumn{2}{c}{ Theil T } & 1993 & 1998 \\
\cline { 2 - 5 } All & 1993 & 1998 & 0.49 & 0.48 \\
Rural & 0.46 & 0.46 & 0.45 & 0.45 \\
Urban & 0.40 & 0.38 & 0.49 & 0.51 \\
Within group & 0.42 & 0.50 & - & - \\
Between group & 0.41 & 0.42 & - & - \\
Regions & 0.05 & 0.04 & & \\
Northern Uplands & & & 0.38 & 0.39 \\
Red River Delta & 0.26 & 0.27 & 0.45 & 0.49 \\
North Central Coast & 0.39 & 0.50 & 0.42 & 0.42 \\
South Central Coast & 0.38 & 0.35 & 0.49 & 0.47 \\
Central Highlands & 0.44 & 0.46 & 0.45 & 0.50 \\
South East & 0.37 & 0.44 & 0.50 & 0.48 \\
Mekong Delta & 0.46 & 0.42 & 0.48 & 0.47 \\
Within group & 0.45 & 0.41 & - & - \\
Between group & 0.41 & 0.41 & - & - \\
\hline Source: Authors own & 0.05 & 0.04 & & \\
\hline
\end{tabular}

Source: Author's own calculations using VNLSS 93 and 98.

The growth incidence curves, which plot the average growth in income by percentiles, visually present the distribution of growth in incomes for different groups of households (Fig.4). The poorer households in the rural areas experience a higher growth than average ${ }^{21}$ which indicates that rural poverty has declined in 1993-1998, which is

\footnotetext{
${ }^{21}$ The average growth displayed is the growth rate in mean.
} 
consistent with what we observe. Similarly, the income growth of the poorest households (lowest decile) in urban is much higher than the average, while richer households experience a lower than average growth.

\section{Figure 4. Growth Incidence Curves}
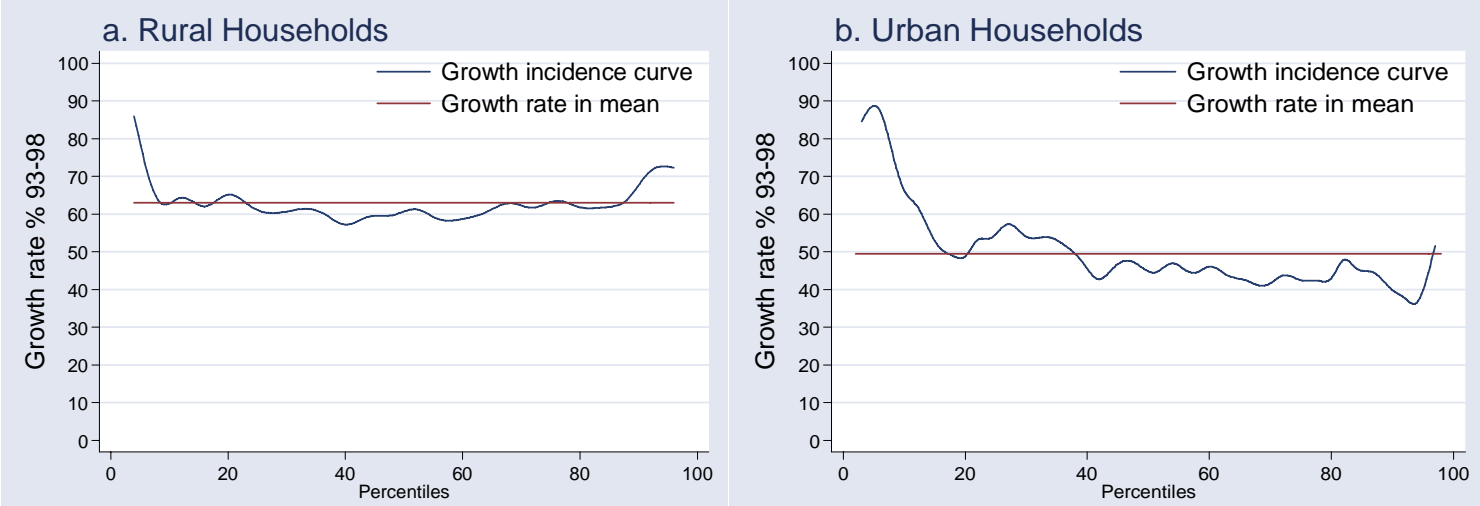

c. Net Seller Households

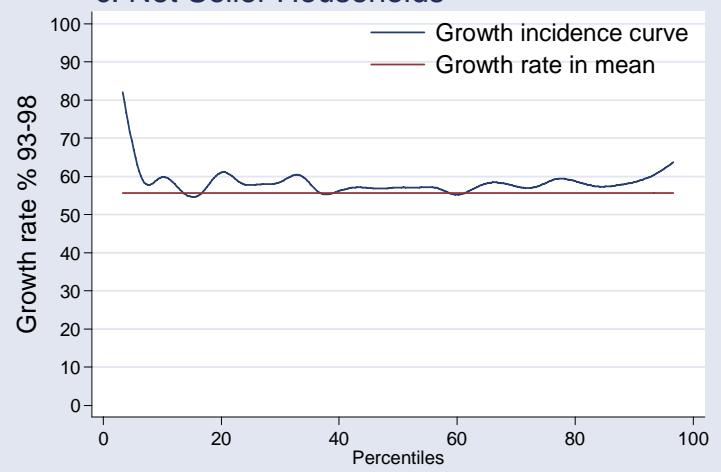

d. Net Buyer Households

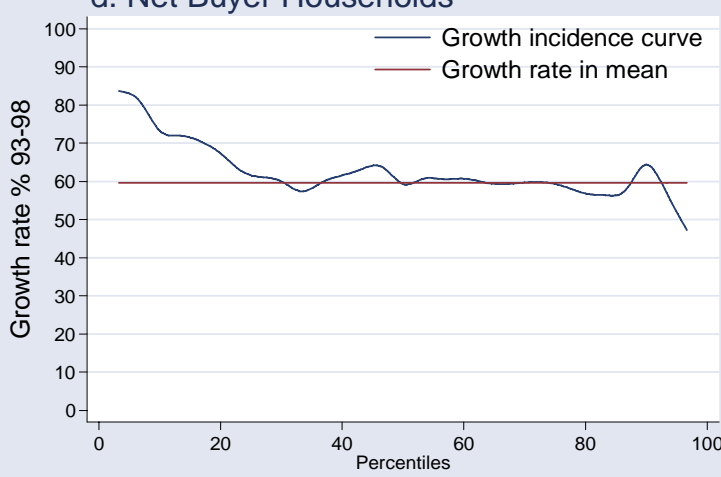

e. Large (Intense) Buyer Households
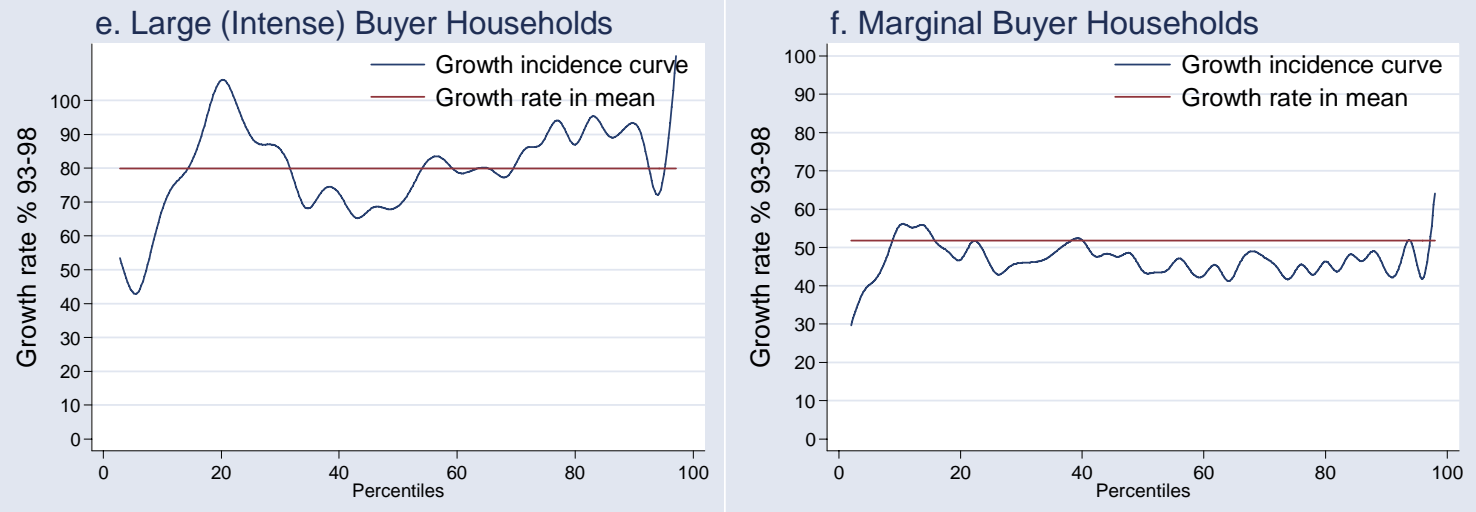

The income growth has definitely been pro-poor in rural areas. Similarly, the poor net buyer households have experienced a higher than average income growths while their richer counterparts less so, although the income growth for the richer is still around 55\%. 
For the net seller households, the distribution of the growth is pretty even except for the higher growth rates for the poor. The growth incidence curves summarize the growth experiences of households compactly; however, they do not illustrate the importance of the links, which is reported in the next subsection.

\subsection{Decomposition}

The decomposition of income growth for different categories of households is presented in Table 9. The contribution of each source is presented such that their sum equals the total income growth experienced by those households. Confirming our insights from the growth incidence curves, Table 9 indicates that the lower income ${ }^{22}$ households experienced a larger income growth compared to middle income and richer households both in rural and urban areas. The majority of the growth for poorer households in rural was due to the increase in agricultural income (50\%), a significant part of which is from crop profit (Table A.5). Moreover, the business income and non-agricultural wages contribute a healthy amount to the overall growth underscoring the importance of development effects. On the other hand, business income and non-agricultural wages along with remittances were the driving forces for the growth experienced by lower income households residing in urban areas ${ }^{23}$.

Rural net-buyers and rural households in the South are the only groups that do not experience a negative contribution from agricultural wages (Table A.5). Although rice is a labor intensive good, the nature of the land distribution in Vietnam may be a major reason for the small agricultural labor. The laborers in agriculture are mostly net buyers from rural areas. Hence, the effect of an increase in rice price on the agricultural wages and employment is small and only experienced by a certain group of households.

For net-sellers in rural areas profit from crops is the biggest contributor, with rice corresponding to more than half of it. The business income and other wages also have a significant impact on total income growth. Poorer households again experience a higher growth compared to their middle income and richer counterparts.

\footnotetext{
${ }^{22}$ The deciles in these analyses are constructed using per capita adjusted income, and 1993 characteristics (deciles, subgroups) are used to trace the growth for the same group of households. The lowest $40 \%$ in a given group corresponds to all the households that were in the group and also in the lowest 4 deciles of the overall income distribution.

${ }^{23}$ See Table A.5 in the Annex for a detailed decomposition.
} 
Table 9. Decomposition of the Income Growth from 1993 to 1998.

\begin{tabular}{|c|c|c|c|c|c|c|}
\hline & $\begin{array}{l}\text { Agricultural } \\
\text { Income }\end{array}$ & $\begin{array}{c}\text { Non-Farm } \\
\text { self } \\
\text { employment }\end{array}$ & $\begin{array}{c}\text { Wage } \\
\text { Income }\end{array}$ & $\begin{array}{c}\text { Other } \\
\text { Income }\end{array}$ & $\begin{array}{c}\text { Total } \\
\text { Growth }\end{array}$ & $\begin{array}{c}\% \text { of the sub- } \\
\text { sample in the } \\
\text { population }\end{array}$ \\
\hline \multicolumn{7}{|l|}{ RURAL } \\
\hline Lowest $40 \%$ & $50 \%$ & $10 \%$ & $5 \%$ & $10 \%$ & $75 \%$ & $38 \%$ \\
\hline Middle 40\% & $26 \%$ & $10 \%$ & $6 \%$ & $15 \%$ & $57 \%$ & $33 \%$ \\
\hline Top 20\% & $23 \%$ & $12 \%$ & $11 \%$ & $12 \%$ & $59 \%$ & $10 \%$ \\
\hline Total & $35 \%$ & $10 \%$ & $6 \%$ & $12 \%$ & $63 \%$ & $81 \%$ \\
\hline \multicolumn{7}{|l|}{ URBAN } \\
\hline Lowest $40 \%$ & $7 \%$ & $28 \%$ & $14 \%$ & $24 \%$ & $73 \%$ & $3 \%$ \\
\hline Middle 40\% & $8 \%$ & $22 \%$ & $18 \%$ & $14 \%$ & $62 \%$ & $7 \%$ \\
\hline Top 20\% & $1 \%$ & $15 \%$ & $12 \%$ & $14 \%$ & $43 \%$ & $9 \%$ \\
\hline Total & $3 \%$ & $18 \%$ & $13 \%$ & $15 \%$ & $49 \%$ & $19 \%$ \\
\hline & $\begin{array}{c}\text { Agricultural } \\
\text { Income }\end{array}$ & $\begin{array}{c}\text { Non-Farm } \\
\text { self } \\
\text { employment }\end{array}$ & $\begin{array}{c}\text { Wage } \\
\text { Income }\end{array}$ & $\begin{array}{c}\text { Other } \\
\text { Income }\end{array}$ & $\begin{array}{c}\text { Total } \\
\text { Growth }\end{array}$ & $\begin{array}{c}\% \text { of the sub- } \\
\text { sample in the } \\
\text { population }\end{array}$ \\
\hline \multicolumn{7}{|c|}{$\begin{array}{l}\text { RURAL-NET } \\
\text { BUYER }\end{array}$} \\
\hline Lowest $40 \%$ & $46 \%$ & $9 \%$ & $10 \%$ & $12 \%$ & $77 \%$ & $20 \%$ \\
\hline Middle 40\% & $29 \%$ & $11 \%$ & $8 \%$ & $19 \%$ & $66 \%$ & $15 \%$ \\
\hline Top 20\% & $24 \%$ & $16 \%$ & $15 \%$ & $14 \%$ & $69 \%$ & $5 \%$ \\
\hline Total & $36 \%$ & $11 \%$ & $10 \%$ & $14 \%$ & $71 \%$ & $40 \%$ \\
\hline \multicolumn{7}{|c|}{$\begin{array}{l}\text { RURAL NET } \\
\text { SELLER }\end{array}$} \\
\hline Lowest $40 \%$ & $54 \%$ & $10 \%$ & $-1 \%$ & $9 \%$ & $72 \%$ & $18 \%$ \\
\hline Middle 40\% & $23 \%$ & $9 \%$ & $5 \%$ & $13 \%$ & $50 \%$ & $18 \%$ \\
\hline Top 20\% & $20 \%$ & $9 \%$ & $9 \%$ & $9 \%$ & $46 \%$ & $5 \%$ \\
\hline Total & $33 \%$ & $10 \%$ & $3 \%$ & $11 \%$ & $56 \%$ & $41 \%$ \\
\hline \multicolumn{7}{|c|}{ RURAL SOUTH } \\
\hline Lowest $40 \%$ & $65 \%$ & $12 \%$ & $6 \%$ & $12 \%$ & $95 \%$ & $13 \%$ \\
\hline Middle $40 \%$ & $37 \%$ & $12 \%$ & $10 \%$ & $18 \%$ & $77 \%$ & $15 \%$ \\
\hline Top 20\% & $28 \%$ & $15 \%$ & $14 \%$ & $13 \%$ & $70 \%$ & $7 \%$ \\
\hline Total & $44 \%$ & $13 \%$ & $8 \%$ & $15 \%$ & $79 \%$ & $35 \%$ \\
\hline \multicolumn{7}{|c|}{ RURAL NORTH } \\
\hline Lowest $40 \%$ & $40 \%$ & $8 \%$ & $6 \%$ & $9 \%$ & $63 \%$ & $25 \%$ \\
\hline Middle 40\% & $15 \%$ & $7 \%$ & $4 \%$ & $12 \%$ & $39 \%$ & $18 \%$ \\
\hline Top 20\% & $12 \%$ & $7 \%$ & $5 \%$ & $6 \%$ & $31 \%$ & $3 \%$ \\
\hline Total & $25 \%$ & $8 \%$ & $5 \%$ & $10 \%$ & $48 \%$ & $47 \%$ \\
\hline
\end{tabular}

Another interesting thing to note is the role of cash crop income in Rural South. The profit from crops constitutes the largest component of the income growth. On average, the food crops (excluding rice) and cash crops each contributed almost as much as rice, with cash crop playing a larger role than rice for poorer households living in 
Rural South. This indicates the introduction of cash crops (such as coffee) in rural areas and specialization.

The ex-post decomposition allows us to observe the various channels that were discussed previously. However, we refrain from attributing all the observed changes to change in trade policy. A more formal empirical analysis is undertaken to find the effect of certain characteristics on income growth.

\subsection{Growth in Expenditure}

Although income is used as the welfare measure, in order to keep the comparability with the literature, the growth of expenditure is also reported. This will allow us to examine the net welfare growth (income-expenditure) that is used in ex-ante studies $^{24}$. The changes in expenditure are similar to income for most categories of households albeit smaller (see Table A.6). The exception is the regions, where households in North Central Coast and South East experience the highest increase in expenditure. The net change in welfare indicates that net buyers gained more than net sellers (even after taking into account the increased expenditure due to higher prices). Marginal buyers gained the most followed by medium buyers and large buyers. Overall rural households gained more than their urban counterparts. Among regions, Central Highlands benefited most, while households in Red River Delta gained the least.

\subsection{Empirical Results}

\section{Income determinants}

Exploiting the panel nature of the data, we estimate the determinants of income using a fixed effects model. The results which are presented in Table A.7 in Appendix1 confirm our expectations. Households who have a higher share of cash crop income have a higher household income ceteris paribus. Moreover, on average, net seller households have more income than the net buyer ones in urban areas, while it doesn't have a significant effect in rural areas. The returns to education are significant for all households, the more education the household head has, the higher household income is. Age of the household head, which is used as a proxy for experience, is positive and

\footnotetext{
${ }^{24}$ For instance, Deaton's (1989) Net Benefit Ratio is a net welfare measure that takes both income and expenditure side into account.
} 
significant for all households, as well as those in rural areas. In addition, on average households who are in manufacturing and other non agricultural sectors have higher incomes than ones in the agriculture, underscoring the relative poverty of farmers. Furthermore, male headed households have 14\% more household income on average. The regional effects are picked up under the fixed effects and hence are not significant as independent variables in the estimation.

\section{Change in Welfare}

The results of the estimation of (3) for rural and urban households are presented in Tables A.9-A.10 respectively. The change in income related variables are added separately to determine the association of each with the growth. The various models presented in the tables correspond to each of the change variables being added into the estimation.

Looking at the characteristics of the household head, neither the age nor the gender of the household head has an effect in changes in income for urban while age positively effects the growth in rural. Initial education of the household positively impacts the growth, although interestingly only at the lower secondary and undergraduate level. For rural regression, regional variables show that households that live in Central Coasts (both North and South), Southeast and Mekong Delta experience a higher growth in income compared to households in Northern Uplands, which is consistent with our earlier growth figures. In terms of the endowments, having a larger land seem to not have a significant effect on the growth in income while returns to land is mildly significant for rural households. With respect to the income sources, holding everything else constant, the households that were food crop producers initially had a higher income growth. Moreover, while an increase in the share of food crop over the years does not have an impact, the increase in shares of non-farm business income and non-agricultural wages have a positive and significant effect on household welfare. This is not surprising given the results of the decomposition, and emphasizes the significance of the multiplier effect. Furthermore, households who switched from being a net buyer of rice to net seller have gained more compared to ones who switched from seller to buyer.

The results for the urban area are similar to rural estimates with few important differences. First, the regional effects are not significant for the urban households, except 
for the Red River Delta region. Moreover, being initially a food crop producer in urban does not have a significant effect on change in household income. Changes in the structure of the income sources, namely changes in the share of food crop income, cash crop income and business do not provide a clear interpretation, potentially due to the correlation between these variables. Most of these results are intuitive and reinforce our earlier findings. However, as mentioned earlier, due to potential simultaneity with respect to change variables, we focus on the associations without pressing for causality.

\section{CONCLUSION}

In this paper, we analyze the importance of different channels that link trade reforms and household welfare. Most studies capture only one, at most two, of these channels and hence the results are incomplete. Thus, analysis of the role of each link (even though indirectly) by looking at the data was the principal purpose. In addition, we investigate how different groups of households are affected from trade liberalization, using Vietnam as a case study for both. Using the panel component of 1993 \& 1998 household surveys, we study the changes in welfare for different categories of households, and provide a decomposition of the growth by income sources.

Our results indicate that the growth has been broad-based and pro-poor. Poorer households experienced higher income growth for each and every category of households analyzed. In addition, net buyer households have gained more than net seller households, indicating that the first-order effects prevalent in the literature are not good representations of the overall effect. Furthermore, significant amount of switch between the two groups (net-seller and net buyer) indicates that net seller-buyer categories may not be appropriate to study the effect on households.

The decomposition of the growth in income indicates that the two most important links for rural households are the agricultural income (direct-effect) and non-farm employment (business income and wages). The direct effect is most important for netseller households and households that lived in South. The development effect, the spillover effect of changes in incomes through increased demand for local goods and services, proves to be a significant part of the growth. Business income and non-agricultural wages along with remittances were the driving forces for the growth experienced by households 
residing in urban areas, underscoring the contribution of the development effect. The labor market link is not significant for most of the households except rural net-buyers and households in rural South.

Results of the empirical analysis confirm our earlier findings, and point to other factors. For instance, share of cash crop income is a positive determinant for household income. In addition, the increase in non-farm business income and non-agricultural wages are associated with higher gains in income for rural households. These results indicate a strong association albeit without making a claim to causality due to potential simultaneity of the change variables.

Overall, the results indicate that trade reforms has benefited everybody but especially the poor. The evidence on the magnitude of the spill-over effects, often ignored in simulations, underscores the need for a broader model to successfully simulate the impact of trade liberalization. 


\section{REFERENCES}

Barrett, C. B., and P. A. Dorosh. 1996. Farmers' welfare and changing food prices: Nonparametric evidence from rice in Madagascar. American Journal of Agricultural Economics 78: 656-669.

Benjamin, D., and L. Brandt. 2004. "Agriculture and Income Distribution in Rural Vietnam under Economic Reforms: A Tale of Two Regions”. In Glewwe, P., N. Agrawal, and D. Dollar (Eds) "Economic Growth, Poverty and Household Welfare in Vietnam”, World Bank, pp. 133-186.

Budd, J. W. 1993. Changing food prices and rural welfare: A nonparametric examination of the Côte d’Ivoire. Economic Development and Cultural Change 41: 587-603.

Deaton, A. 1989. Rice prices and income distribution in Thailand: A non-parametric analysis. The Economic Journal 99 (supplement): 1-37.

Deaton, A. 1997. "The Analysis of Household Surveys. A Microeconometric Approach to Development Policy”, The World Bank and The Johns Hopkins University Press.

Dercon, S. 2005. Economic reform, growth and the poor: Evidence from rural Ethiopia. Journal of Development Economics (forthcoming)

Glewwe, P., M. Gragnolati, and H .Zaman. 2000. Who gained from Vietnam's boom in the 1990's? An Analysis of Poverty and Inequality Trends. World Bank Policy Research Working Paper Series No: 2275.

Litchfield, J.A., N.M. McCulloch, and L.A.Winters. 2003. Agricultural Trade Liberalization and Poverty Dynamics in Three Developing Countries. American Journal of Agricultural Economics 85: 1285-1291.

Mellor, J. 1978. Food price policy and income distribution in low-income countries. Economic Development and Cultural Change 27: 1-26.

Minot, N. and Goletti, F. 2000. "Rice Market Liberalization and Poverty in Vietnam. International Food Policy Research Institute Research Report No: 114, Washington D.C.

Nicita, A. 2004. Who benefited from trade liberalization in Mexico? Measuring the effects on household welfare. World Bank Policy Research Working Paper Series No: 3265.

Niimi, Y., P. Vasudeva-Dutta, and L.A. Winters. 2003. Trade Liberalization and Poverty Dynamics in Vietnam. Poverty Research Unit at Sussex Working Paper No: 17.

Ravallion, M. 1990. Rural Welfare Effects of Food Price Changes under Induced Wage Responses: Theory and Evidence for Bangladesh. Oxford Economic Papers 42: 574-585 
Reimer, J. J. 2002. Estimating the Poverty Impacts of Trade Liberalization. World Bank Policy Research Working Paper Series No: 2790.

Singh, I., L. Squire and, J. Strauss. 1986. “Agricultural household models: Extensions, applications, and policy”, Johns Hopkins University Press for the World Bank.

Porto, G. 2003. Trade reforms, market access and poverty in Argentina. World Bank Policy Research Working Paper Series No: 3135.

Porto, G. 2005. Estimating Household Responses to Trade Reforms: Net Consumers and Net Producers in Rural Mexico. World Bank Policy Research Working Paper Series No: 3695.

Van De Walle, D. and D. Cratty. 2003. Is the Emerging Non-Farm Market Economy the Route Out of Poverty in Vietnam? World Bank Policy Research Working Paper Series No: 2950.

Winters, L. A. 2002. Trade liberalisation and poverty: what are the links? World Economy (U.K.) 25(9): 1339-67.

World Bank. 1999. Vietnam Development Report 2000: Attacking Poverty. Country Economic Memorandum, Washington DC. 


\section{Appendix 1}

Table A.1 Detailed Sources of Income for Rural Households in 1993

\begin{tabular}{|c|c|c|c|c|c|c|c|c|c|c|c|}
\hline Sources of Income & 1 & 2 & 3 & 4 & 5 & 6 & 7 & 8 & 9 & 10 & Total \\
\hline Profit from rice & $3 \%$ & $6 \%$ & $6 \%$ & $6 \%$ & $7 \%$ & $7 \%$ & $7 \%$ & $6 \%$ & $7 \%$ & $-1 \%$ & $6 \%$ \\
\hline Net own consumption rice & $21 \%$ & $27 \%$ & $22 \%$ & $17 \%$ & $19 \%$ & $16 \%$ & $14 \%$ & $12 \%$ & $10 \%$ & $6 \%$ & $18 \%$ \\
\hline Profits from other food crops & $3 \%$ & $3 \%$ & $3 \%$ & $3 \%$ & $3 \%$ & $3 \%$ & $4 \%$ & $3 \%$ & $3 \%$ & $3 \%$ & $3 \%$ \\
\hline Profits from cash crops & $2 \%$ & $3 \%$ & $4 \%$ & $2 \%$ & $5 \%$ & $4 \%$ & $4 \%$ & $4 \%$ & $5 \%$ & $6 \%$ & $4 \%$ \\
\hline Net own consumption all other food & $16 \%$ & $12 \%$ & $10 \%$ & $7 \%$ & $12 \%$ & $8 \%$ & $7 \%$ & $9 \%$ & $7 \%$ & $15 \%$ & $10 \%$ \\
\hline Net Livestock Income & $15 \%$ & $10 \%$ & $15 \%$ & $8 \%$ & $14 \%$ & $13 \%$ & $19 \%$ & $11 \%$ & $8 \%$ & $11 \%$ & $13 \%$ \\
\hline Other Agricultural & $0 \%$ & $1 \%$ & $1 \%$ & $1 \%$ & $-1 \%$ & $5 \%$ & $0 \%$ & $4 \%$ & $0 \%$ & $0 \%$ & $1 \%$ \\
\hline Non farm self employment & $9 \%$ & $10 \%$ & $10 \%$ & $12 \%$ & $14 \%$ & $14 \%$ & $15 \%$ & $17 \%$ & $23 \%$ & $22 \%$ & $13 \%$ \\
\hline Wages from Agriculture & $13 \%$ & $11 \%$ & $9 \%$ & $21 \%$ & $7 \%$ & $7 \%$ & $6 \%$ & $8 \%$ & $3 \%$ & $3 \%$ & $9 \%$ \\
\hline Other Wages & $8 \%$ & $6 \%$ & $8 \%$ & $9 \%$ & $8 \%$ & $9 \%$ & $8 \%$ & $12 \%$ & $10 \%$ & $9 \%$ & $9 \%$ \\
\hline Remittances & $4 \%$ & $2 \%$ & $4 \%$ & $3 \%$ & $3 \%$ & $4 \%$ & $4 \%$ & $4 \%$ & $6 \%$ & $4 \%$ & $4 \%$ \\
\hline Other Income & $6 \%$ & $9 \%$ & $9 \%$ & $12 \%$ & $10 \%$ & $10 \%$ & $12 \%$ & $10 \%$ & $18 \%$ & $20 \%$ & $11 \%$ \\
\hline Income (thousand dongs) & 3954.1 & 4616.9 & 5649.9 & 6697.8 & 7159.7 & 7504.8 & 9527.2 & 10542.0 & 11141.5 & 18121.2 & 7631.0 \\
\hline Total & $100 \%$ & $100 \%$ & $100 \%$ & $100 \%$ & $100 \%$ & $100 \%$ & $100 \%$ & $100 \%$ & $100 \%$ & $100 \%$ & $100 \%$ \\
\hline
\end{tabular}

Table A.2 Detailed Sources of Income for Urban Households in 1993

\begin{tabular}{|c|c|c|c|c|c|c|c|c|c|c|c|}
\hline Sources of Income & 1 & 2 & 3 & 4 & 5 & 6 & 7 & 8 & 9 & 10 & Total \\
\hline Profit from rice & $4 \%$ & $-1 \%$ & $2 \%$ & $0 \%$ & $1 \%$ & $1 \%$ & $0 \%$ & $1 \%$ & $0 \%$ & $0 \%$ & $1 \%$ \\
\hline Net own consumption rice & $8 \%$ & $3 \%$ & $8 \%$ & $2 \%$ & $5 \%$ & $2 \%$ & $4 \%$ & $3 \%$ & $1 \%$ & $0 \%$ & $2 \%$ \\
\hline Profits from other food crops & $4 \%$ & $0 \%$ & $4 \%$ & $2 \%$ & $1 \%$ & $3 \%$ & $0 \%$ & $2 \%$ & $1 \%$ & $0 \%$ & $1 \%$ \\
\hline Profits from cash crops & $3 \%$ & $3 \%$ & $6 \%$ & $2 \%$ & $4 \%$ & $2 \%$ & $1 \%$ & $1 \%$ & $1 \%$ & $0 \%$ & $1 \%$ \\
\hline Net own consumption all other food & $3 \%$ & $9 \%$ & $4 \%$ & $3 \%$ & $5 \%$ & $4 \%$ & $3 \%$ & $3 \%$ & $2 \%$ & $1 \%$ & $3 \%$ \\
\hline Net Livestock Income & $4 \%$ & $2 \%$ & $6 \%$ & $10 \%$ & $4 \%$ & $7 \%$ & $0 \%$ & $1 \%$ & $6 \%$ & $1 \%$ & $3 \%$ \\
\hline Other Agricultural & $0 \%$ & $0 \%$ & $0 \%$ & $-5 \%$ & $2 \%$ & $-5 \%$ & $0 \%$ & $0 \%$ & $0 \%$ & $0 \%$ & $0 \%$ \\
\hline Non farm self employment & $17 \%$ & $30 \%$ & $21 \%$ & $40 \%$ & $31 \%$ & $29 \%$ & $31 \%$ & $34 \%$ & $42 \%$ & $33 \%$ & $34 \%$ \\
\hline Wages from Agriculture & $13 \%$ & $8 \%$ & $12 \%$ & $6 \%$ & $5 \%$ & $5 \%$ & $4 \%$ & $3 \%$ & $2 \%$ & $1 \%$ & $3 \%$ \\
\hline Other Wages & $34 \%$ & $30 \%$ & $27 \%$ & $23 \%$ & $27 \%$ & $32 \%$ & $32 \%$ & $26 \%$ & $24 \%$ & $22 \%$ & $26 \%$ \\
\hline Remittances & $2 \%$ & $3 \%$ & $2 \%$ & $3 \%$ & $3 \%$ & $3 \%$ & $9 \%$ & $7 \%$ & $7 \%$ & $15 \%$ & $8 \%$ \\
\hline Other Income & $7 \%$ & $14 \%$ & $8 \%$ & $13 \%$ & $12 \%$ & $19 \%$ & $17 \%$ & $19 \%$ & $15 \%$ & $25 \%$ & $18 \%$ \\
\hline Income (thousand dongs) & 4082.4 & 7324.6 & 7033.8 & 6984.2 & 7336.1 & 8544.8 & 9974.5 & 12885.2 & 15478.2 & 25271.8 & 15367.8 \\
\hline Total & $100 \%$ & $100 \%$ & $100 \%$ & $100 \%$ & $100 \%$ & $100 \%$ & $100 \%$ & $100 \%$ & $101 \%$ & $100 \%$ & $100 \%$ \\
\hline
\end{tabular}


Table A.3 Detailed Sources of Income for Rural Households in 1998

\begin{tabular}{|c|c|c|c|c|c|c|c|c|c|c|c|}
\hline Sources of Income & 1 & 2 & 3 & 4 & 5 & 6 & 7 & 8 & 9 & 10 & Total \\
\hline Profit from rice & $6 \%$ & $8 \%$ & $8 \%$ & $6 \%$ & $9 \%$ & $11 \%$ & $8 \%$ & $8 \%$ & $7 \%$ & $5 \%$ & $8 \%$ \\
\hline Net own consumption rice & $25 \%$ & $23 \%$ & $16 \%$ & $14 \%$ & $14 \%$ & $12 \%$ & $8 \%$ & $8 \%$ & $4 \%$ & $2 \%$ & $15 \%$ \\
\hline Profits from other food crops & $0 \%$ & $5 \%$ & $5 \%$ & $6 \%$ & $5 \%$ & $6 \%$ & $7 \%$ & $8 \%$ & $5 \%$ & $4 \%$ & $5 \%$ \\
\hline Profits from cash crops & $4 \%$ & $6 \%$ & $5 \%$ & $5 \%$ & $4 \%$ & $6 \%$ & $8 \%$ & $6 \%$ & $6 \%$ & $7 \%$ & $5 \%$ \\
\hline Net own consumption all other food & $10 \%$ & $10 \%$ & $8 \%$ & $8 \%$ & $7 \%$ & $5 \%$ & $7 \%$ & $6 \%$ & $4 \%$ & $4 \%$ & $7 \%$ \\
\hline Net Livestock Income & $18 \%$ & $11 \%$ & $15 \%$ & $17 \%$ & $13 \%$ & $14 \%$ & $11 \%$ & $12 \%$ & $8 \%$ & $7 \%$ & $14 \%$ \\
\hline Other Agricultural & $4 \%$ & $0 \%$ & $0 \%$ & $1 \%$ & $2 \%$ & $1 \%$ & $1 \%$ & $0 \%$ & $1 \%$ & $1 \%$ & $1 \%$ \\
\hline Non farm self employment & $8 \%$ & $10 \%$ & $12 \%$ & $13 \%$ & $14 \%$ & $17 \%$ & $16 \%$ & $20 \%$ & $24 \%$ & $22 \%$ & $14 \%$ \\
\hline Wages from Agriculture & $10 \%$ & $8 \%$ & $7 \%$ & $5 \%$ & $5 \%$ & $3 \%$ & $2 \%$ & $2 \%$ & $2 \%$ & $1 \%$ & $5 \%$ \\
\hline Other Wages & $8 \%$ & $7 \%$ & $10 \%$ & $11 \%$ & $10 \%$ & $9 \%$ & $9 \%$ & $7 \%$ & $11 \%$ & $10 \%$ & $9 \%$ \\
\hline Remittances & $2 \%$ & $3 \%$ & $3 \%$ & $4 \%$ & $5 \%$ & $4 \%$ & $6 \%$ & $7 \%$ & $10 \%$ & $19 \%$ & $5 \%$ \\
\hline Other Income & $5 \%$ & $9 \%$ & $10 \%$ & $12 \%$ & $12 \%$ & $14 \%$ & $17 \%$ & $15 \%$ & $18 \%$ & $17 \%$ & $12 \%$ \\
\hline Income (thousand dongs) & 6218.8 & 7732.7 & 9593.4 & 10540.0 & 11470.5 & 13867.1 & 15578.3 & 18321.6 & 28031.5 & 33273.7 & 12269.4 \\
\hline Total & $100 \%$ & $100 \%$ & $100 \%$ & $100 \%$ & $100 \%$ & $100 \%$ & $100 \%$ & $100 \%$ & $100 \%$ & $100 \%$ & $100 \%$ \\
\hline
\end{tabular}

Table A.4 Detailed Sources of Income for Urban Households in 1998

\begin{tabular}{|c|c|c|c|c|c|c|c|c|c|c|c|}
\hline Sources of Income & 1 & 2 & 3 & 4 & 5 & 6 & 7 & 8 & 9 & 10 & Total \\
\hline Profit from rice & $4 \%$ & $3 \%$ & $3 \%$ & $0 \%$ & $6 \%$ & $2 \%$ & $2 \%$ & $2 \%$ & $1 \%$ & $0 \%$ & $1 \%$ \\
\hline Net own consumption rice & $2 \%$ & $7 \%$ & $3 \%$ & $1 \%$ & $4 \%$ & $4 \%$ & $3 \%$ & $2 \%$ & $1 \%$ & $0 \%$ & $2 \%$ \\
\hline Profits from other food crops & $0 \%$ & $1 \%$ & $1 \%$ & $2 \%$ & $2 \%$ & $1 \%$ & $1 \%$ & $2 \%$ & $2 \%$ & $0 \%$ & $1 \%$ \\
\hline Profits from cash crops & $1 \%$ & $0 \%$ & $0 \%$ & $2 \%$ & $4 \%$ & $2 \%$ & $1 \%$ & $1 \%$ & $1 \%$ & $1 \%$ & $1 \%$ \\
\hline Net own consumption all other food & $5 \%$ & $5 \%$ & $2 \%$ & $2 \%$ & $3 \%$ & $2 \%$ & $1 \%$ & $3 \%$ & $1 \%$ & $3 \%$ & $2 \%$ \\
\hline Net Livestock Income & $0 \%$ & $4 \%$ & $3 \%$ & $8 \%$ & $6 \%$ & $2 \%$ & $12 \%$ & $3 \%$ & $2 \%$ & $0 \%$ & $4 \%$ \\
\hline Other Agricultural & $0 \%$ & $2 \%$ & $0 \%$ & $3 \%$ & $0 \%$ & $0 \%$ & $0 \%$ & $0 \%$ & $0 \%$ & $0 \%$ & $\mathbf{0 \%}$ \\
\hline Non farm self employment & $26 \%$ & $25 \%$ & $45 \%$ & $26 \%$ & $23 \%$ & $41 \%$ & $33 \%$ & $33 \%$ & $39 \%$ & $32 \%$ & $34 \%$ \\
\hline Wages from Agriculture & $2 \%$ & $5 \%$ & $0 \%$ & $2 \%$ & $4 \%$ & $0 \%$ & $1 \%$ & $1 \%$ & $1 \%$ & $0 \%$ & $1 \%$ \\
\hline Other Wages & $43 \%$ & $34 \%$ & $31 \%$ & $29 \%$ & $25 \%$ & $26 \%$ & $25 \%$ & $25 \%$ & $27 \%$ & $26 \%$ & $27 \%$ \\
\hline Remittances & $5 \%$ & $3 \%$ & $1 \%$ & $9 \%$ & $6 \%$ & $6 \%$ & $9 \%$ & $11 \%$ & $9 \%$ & $14 \%$ & $10 \%$ \\
\hline Other Income & $13 \%$ & $11 \%$ & $10 \%$ & $16 \%$ & $17 \%$ & $13 \%$ & $16 \%$ & $16 \%$ & $16 \%$ & $23 \%$ & $17 \%$ \\
\hline Income (thousand dongs) & 8153.0 & 8675.5 & 9131.9 & 9809.7 & 9964.8 & 12355.0 & 13831.2 & 16993.3 & 24351.6 & 43264.8 & 22513.1 \\
\hline Total & $100 \%$ & $100 \%$ & $100 \%$ & $100 \%$ & $100 \%$ & $100 \%$ & $103 \%$ & $100 \%$ & $100 \%$ & $100 \%$ & $100 \%$ \\
\hline
\end{tabular}


Table A.5 Detailed Decomposition of Growth in Total Income, 1993-1998

\begin{tabular}{|c|c|c|c|c|c|c|c|c|c|c|c|c|}
\hline & $\begin{array}{c}\text { Profit } \\
\text { from rice }\end{array}$ & $\begin{array}{l}\text { Profit } \\
\text { from } \\
\text { food } \\
\text { crops }\end{array}$ & $\begin{array}{l}\text { Profit } \\
\text { from } \\
\text { cash } \\
\text { crops }\end{array}$ & $\begin{array}{c}\text { Other } \\
\text { Agriculture }\end{array}$ & $\begin{array}{c}\text { Net } \\
\text { Livestock } \\
\text { Income } \\
\end{array}$ & $\begin{array}{c}\text { Non Farm } \\
\text { self } \\
\text { employment }\end{array}$ & $\begin{array}{c}\text { Agricultural } \\
\text { wages }\end{array}$ & $\begin{array}{c}\text { Non- } \\
\text { Agricultural } \\
\text { Wages } \\
\end{array}$ & Remittances & $\begin{array}{c}\text { Other } \\
\text { Income }\end{array}$ & $\begin{array}{l}\text { Total } \\
\text { Growth }\end{array}$ & $\begin{array}{l}\text { \% of the } \\
\text { sub- } \\
\text { sample in } \\
\text { the } \\
\text { population }\end{array}$ \\
\hline \multicolumn{13}{|l|}{ RURAL } \\
\hline Lowest 40\% & $6 \%$ & $5 \%$ & $6 \%$ & $19 \%$ & $13 \%$ & $10 \%$ & $-2 \%$ & $7 \%$ & $3 \%$ & $7 \%$ & $75 \%$ & $38 \%$ \\
\hline Middle 40\% & $7 \%$ & $4 \%$ & $3 \%$ & $5 \%$ & $7 \%$ & $10 \%$ & $0 \%$ & $6 \%$ & $5 \%$ & $11 \%$ & $57 \%$ & $33 \%$ \\
\hline Top 20\% & $7 \%$ & $9 \%$ & $4 \%$ & $-1 \%$ & $4 \%$ & $12 \%$ & $1 \%$ & $10 \%$ & $7 \%$ & $4 \%$ & $59 \%$ & $10 \%$ \\
\hline Total & $7 \%$ & $5 \%$ & $5 \%$ & $9 \%$ & $9 \%$ & $10 \%$ & $-1 \%$ & $7 \%$ & $4 \%$ & $8 \%$ & $63 \%$ & $81 \%$ \\
\hline \multicolumn{13}{|l|}{ URBAN } \\
\hline Lowest 40\% & $3 \%$ & $1 \%$ & $-1 \%$ & $3 \%$ & $0 \%$ & $28 \%$ & $-3 \%$ & $17 \%$ & $14 \%$ & $10 \%$ & $73 \%$ & $3 \%$ \\
\hline Middle 40\% & $2 \%$ & $1 \%$ & $1 \%$ & $1 \%$ & $3 \%$ & $22 \%$ & $-1 \%$ & $19 \%$ & $4 \%$ & $10 \%$ & $62 \%$ & $7 \%$ \\
\hline Top 20\% & $1 \%$ & $0 \%$ & $0 \%$ & $2 \%$ & $-1 \%$ & $15 \%$ & $-1 \%$ & $13 \%$ & $7 \%$ & $8 \%$ & $43 \%$ & $9 \%$ \\
\hline Total & $1 \%$ & $0 \%$ & $0 \%$ & $1 \%$ & $0 \%$ & $18 \%$ & $-2 \%$ & $15 \%$ & $7 \%$ & $8 \%$ & $49 \%$ & $19 \%$ \\
\hline \multicolumn{13}{|c|}{ RURAL-NET BUYER } \\
\hline Lowest 40\% & $3 \%$ & $6 \%$ & $8 \%$ & $18 \%$ & $11 \%$ & $9 \%$ & $2 \%$ & $8 \%$ & $4 \%$ & $7 \%$ & $77 \%$ & $20 \%$ \\
\hline Middle 40\% & $3 \%$ & $3 \%$ & $6 \%$ & $7 \%$ & $8 \%$ & $11 \%$ & $0 \%$ & $8 \%$ & $6 \%$ & $13 \%$ & $66 \%$ & $15 \%$ \\
\hline Top 20\% & $2 \%$ & $8 \%$ & $6 \%$ & $0 \%$ & $7 \%$ & $16 \%$ & $1 \%$ & $13 \%$ & $11 \%$ & $3 \%$ & $69 \%$ & $5 \%$ \\
\hline Total & $3 \%$ & $5 \%$ & $7 \%$ & $11 \%$ & $10 \%$ & $11 \%$ & $1 \%$ & $8 \%$ & $5 \%$ & $9 \%$ & $71 \%$ & $40 \%$ \\
\hline \multicolumn{13}{|c|}{ RURAL-NET SELLER } \\
\hline Lowest $40 \%$ & $10 \%$ & $5 \%$ & $5 \%$ & $19 \%$ & $16 \%$ & $10 \%$ & $-6 \%$ & $6 \%$ & $3 \%$ & $6 \%$ & $72 \%$ & $18 \%$ \\
\hline Middle 40\% & $9 \%$ & $5 \%$ & $1 \%$ & $2 \%$ & $6 \%$ & $9 \%$ & $0 \%$ & $5 \%$ & $4 \%$ & $9 \%$ & $50 \%$ & $18 \%$ \\
\hline Top 20\% & $11 \%$ & $9 \%$ & $3 \%$ & $-3 \%$ & $0 \%$ & $9 \%$ & $1 \%$ & $8 \%$ & $4 \%$ & $5 \%$ & $46 \%$ & $5 \%$ \\
\hline Total & $9 \%$ & $5 \%$ & $3 \%$ & $7 \%$ & $9 \%$ & $10 \%$ & $-3 \%$ & $5 \%$ & $3 \%$ & $7 \%$ & $56 \%$ & $41 \%$ \\
\hline \multicolumn{13}{|c|}{ URBAN-NET BUYER } \\
\hline Lowest 40\% & $1 \%$ & $1 \%$ & $-1 \%$ & $4 \%$ & $0 \%$ & $29 \%$ & $-4 \%$ & $18 \%$ & $15 \%$ & $12 \%$ & $76 \%$ & $2 \%$ \\
\hline Middle 40\% & $1 \%$ & $1 \%$ & $1 \%$ & $1 \%$ & $2 \%$ & $22 \%$ & $-2 \%$ & $20 \%$ & $4 \%$ & $10 \%$ & $61 \%$ & $6 \%$ \\
\hline Top 20\% & $0 \%$ & $0 \%$ & $0 \%$ & $1 \%$ & $-1 \%$ & $14 \%$ & $-1 \%$ & $13 \%$ & $7 \%$ & $8 \%$ & $41 \%$ & $9 \%$ \\
\hline Total & $1 \%$ & $1 \%$ & $0 \%$ & $1 \%$ & $0 \%$ & $17 \%$ & $-2 \%$ & $15 \%$ & $7 \%$ & $9 \%$ & $48 \%$ & $18 \%$ \\
\hline \multicolumn{13}{|c|}{ URBAN-NET SELLER } \\
\hline Lowest 40\% & $10 \%$ & $-1 \%$ & $2 \%$ & $-15 \%$ & $1 \%$ & $24 \%$ & $2 \%$ & $11 \%$ & $9 \%$ & $-12 \%$ & $31 \%$ & $0.2 \%$ \\
\hline Middle 40\% & $22 \%$ & $1 \%$ & $8 \%$ & $-6 \%$ & $20 \%$ & $34 \%$ & $4 \%$ & $13 \%$ & $-4 \%$ & $9 \%$ & $102 \%$ & $0.5 \%$ \\
\hline
\end{tabular}




\begin{tabular}{|c|c|c|c|c|c|c|c|c|c|c|c|c|}
\hline & $\begin{array}{c}\text { Profit } \\
\text { from rice }\end{array}$ & $\begin{array}{l}\text { Profit } \\
\text { from } \\
\text { food } \\
\text { crops }\end{array}$ & $\begin{array}{l}\text { Profit } \\
\text { from } \\
\text { cash } \\
\text { crops }\end{array}$ & $\begin{array}{c}\text { Other } \\
\text { Agriculture }\end{array}$ & $\begin{array}{c}\text { Net } \\
\text { Livestock } \\
\text { Income } \\
\end{array}$ & $\begin{array}{c}\text { Non Farm } \\
\text { self } \\
\text { employment }\end{array}$ & $\begin{array}{l}\text { Agricultural } \\
\text { wages }\end{array}$ & $\begin{array}{c}\text { Non- } \\
\text { Agricultural } \\
\text { Wages }\end{array}$ & Remittances & $\begin{array}{c}\text { Other } \\
\text { Income }\end{array}$ & $\begin{array}{c}\text { Total } \\
\text { Growth }\end{array}$ & $\begin{array}{c}\text { \% of the } \\
\text { sub- } \\
\text { sample in } \\
\text { the } \\
\text { population }\end{array}$ \\
\hline Top 20\% & $4 \%$ & $-1 \%$ & $3 \%$ & $-8 \%$ & $-8 \%$ & $2 \%$ & $-1 \%$ & $-1 \%$ & $3 \%$ & $-1 \%$ & $-8 \%$ & $0.3 \%$ \\
\hline Total & $12 \%$ & $-1 \%$ & $4 \%$ & $-11 \%$ & $4 \%$ & $20 \%$ & $1 \%$ & $8 \%$ & $2 \%$ & $0 \%$ & $38 \%$ & $1.0 \%$ \\
\hline \multicolumn{13}{|c|}{ RURAL-SOUTH } \\
\hline Lowest $40 \%$ & $11 \%$ & $9 \%$ & $14 \%$ & $20 \%$ & $11 \%$ & $12 \%$ & $-1 \%$ & $7 \%$ & $2 \%$ & $10 \%$ & $95 \%$ & $13 \%$ \\
\hline Middle 40\% & $14 \%$ & $10 \%$ & $6 \%$ & $2 \%$ & $5 \%$ & $12 \%$ & $2 \%$ & $8 \%$ & $5 \%$ & $14 \%$ & $77 \%$ & $15 \%$ \\
\hline Top 20\% & $11 \%$ & $11 \%$ & $7 \%$ & $-4 \%$ & $3 \%$ & $15 \%$ & $2 \%$ & $12 \%$ & $9 \%$ & $4 \%$ & $70 \%$ & $7 \%$ \\
\hline Total & $12 \%$ & $10 \%$ & $9 \%$ & $6 \%$ & $7 \%$ & $13 \%$ & $0 \%$ & $8 \%$ & $5 \%$ & $10 \%$ & $79 \%$ & $35 \%$ \\
\hline \multicolumn{13}{|c|}{ RURAL-NORTH } \\
\hline Lowest $40 \%$ & $4 \%$ & $4 \%$ & $3 \%$ & $16 \%$ & $13 \%$ & $8 \%$ & $-1 \%$ & $7 \%$ & $4 \%$ & $5 \%$ & $63 \%$ & $25 \%$ \\
\hline Middle 40\% & $3 \%$ & $0 \%$ & $2 \%$ & $4 \%$ & $7 \%$ & $7 \%$ & $0 \%$ & $4 \%$ & $4 \%$ & $8 \%$ & $39 \%$ & $18 \%$ \\
\hline Top 20\% & $2 \%$ & $3 \%$ & $1 \%$ & $4 \%$ & $3 \%$ & $7 \%$ & $0 \%$ & $6 \%$ & $3 \%$ & $3 \%$ & $31 \%$ & $3 \%$ \\
\hline Total & $3 \%$ & $2 \%$ & $2 \%$ & $9 \%$ & $9 \%$ & $8 \%$ & $-1 \%$ & $5 \%$ & $4 \%$ & $6 \%$ & $48 \%$ & $47 \%$ \\
\hline \multicolumn{13}{|c|}{ RURAL-MARGINAL NET BUYER } \\
\hline Lowest $40 \%$ & $5 \%$ & $4 \%$ & $6 \%$ & $18 \%$ & $18 \%$ & $13 \%$ & $1 \%$ & $4 \%$ & $6 \%$ & $7 \%$ & $82 \%$ & $5 \%$ \\
\hline Middle 40\% & $4 \%$ & $4 \%$ & $4 \%$ & $-4 \%$ & $9 \%$ & $6 \%$ & $-1 \%$ & $4 \%$ & $4 \%$ & $6 \%$ & $36 \%$ & $5 \%$ \\
\hline Top 20\% & $3 \%$ & $5 \%$ & $14 \%$ & $3 \%$ & $11 \%$ & $20 \%$ & $2 \%$ & $13 \%$ & $14 \%$ & $4 \%$ & $90 \%$ & $2 \%$ \\
\hline Total & $4 \%$ & $4 \%$ & $7 \%$ & $6 \%$ & $13 \%$ & $12 \%$ & $0 \%$ & $6 \%$ & $6 \%$ & $6 \%$ & $65 \%$ & $13 \%$ \\
\hline \multicolumn{13}{|c|}{ RURAL-MEDIUM NET BUYER } \\
\hline Lowest $40 \%$ & $3 \%$ & $5 \%$ & $10 \%$ & $14 \%$ & $13 \%$ & $8 \%$ & $4 \%$ & $5 \%$ & $2 \%$ & $7 \%$ & $71 \%$ & $9 \%$ \\
\hline Middle 40\% & $3 \%$ & $-1 \%$ & $8 \%$ & $15 \%$ & $9 \%$ & $19 \%$ & $2 \%$ & $12 \%$ & $7 \%$ & $19 \%$ & $93 \%$ & $8 \%$ \\
\hline Top 20\% & $1 \%$ & $10 \%$ & $0 \%$ & $-2 \%$ & $3 \%$ & $11 \%$ & $0 \%$ & $12 \%$ & $9 \%$ & $2 \%$ & $47 \%$ & $3 \%$ \\
\hline Total & $3 \%$ & $3 \%$ & $8 \%$ & $12 \%$ & $10 \%$ & $13 \%$ & $2 \%$ & $8 \%$ & $5 \%$ & $11 \%$ & $74 \%$ & $20 \%$ \\
\hline \multicolumn{13}{|c|}{ RURAL-LARGE NET BUYER } \\
\hline Lowest $40 \%$ & $2 \%$ & $8 \%$ & $8 \%$ & $24 \%$ & $1 \%$ & $7 \%$ & $1 \%$ & $17 \%$ & $6 \%$ & $8 \%$ & $84 \%$ & $6 \%$ \\
\hline Middle 40\% & $1 \%$ & $16 \%$ & $8 \%$ & $13 \%$ & $2 \%$ & $-11 \%$ & $-1 \%$ & $2 \%$ & $6 \%$ & $10 \%$ & $47 \%$ & $1 \%$ \\
\hline Top 20\% & - & - & - & - & - & - & - & - & - & - & - & $0 \%$ \\
\hline Total & $2 \%$ & $10 \%$ & $8 \%$ & $21 \%$ & $1 \%$ & $3 \%$ & $0 \%$ & $14 \%$ & $6 \%$ & $9 \%$ & $74 \%$ & $7 \%$ \\
\hline \multicolumn{13}{|c|}{ URBAN-MARGINAL NET BUYER } \\
\hline Lowest $40 \%$ & $53 \%$ & $6 \%$ & $0 \%$ & $-26 \%$ & $42 \%$ & $257 \%$ & $25 \%$ & $-7 \%$ & $-1 \%$ & $12 \%$ & $360 \%$ & $0 \%$ \\
\hline
\end{tabular}




\begin{tabular}{|c|c|c|c|c|c|c|c|c|c|c|c|c|}
\hline & $\begin{array}{c}\text { Profit } \\
\text { from rice }\end{array}$ & $\begin{array}{l}\text { Profit } \\
\text { from } \\
\text { food } \\
\text { crops }\end{array}$ & $\begin{array}{l}\text { Profit } \\
\text { from } \\
\text { cash } \\
\text { crops }\end{array}$ & $\begin{array}{c}\text { Other } \\
\text { Agriculture }\end{array}$ & $\begin{array}{c}\text { Net } \\
\text { Livestock } \\
\text { Income } \\
\end{array}$ & $\begin{array}{c}\text { Non Farm } \\
\text { self } \\
\text { employment }\end{array}$ & $\begin{array}{l}\text { Agricultural } \\
\text { wages }\end{array}$ & $\begin{array}{c}\text { Non- } \\
\text { Agricultural } \\
\text { Wages }\end{array}$ & Remittances & $\begin{array}{c}\text { Other } \\
\text { Income }\end{array}$ & $\begin{array}{c}\text { Total } \\
\text { Growth }\end{array}$ & $\begin{array}{l}\text { \% of the } \\
\text { sub- } \\
\text { sample in } \\
\text { the } \\
\text { population }\end{array}$ \\
\hline Middle $40 \%$ & $7 \%$ & $3 \%$ & $1 \%$ & $2 \%$ & $19 \%$ & $42 \%$ & $0 \%$ & $33 \%$ & $7 \%$ & $8 \%$ & $122 \%$ & $1 \%$ \\
\hline Top 20\% & $1 \%$ & $0 \%$ & $0 \%$ & $2 \%$ & $0 \%$ & $14 \%$ & $0 \%$ & $11 \%$ & $5 \%$ & $5 \%$ & $37 \%$ & $5 \%$ \\
\hline Total & $1 \%$ & $0 \%$ & $0 \%$ & $1 \%$ & $2 \%$ & $16 \%$ & $0 \%$ & $11 \%$ & $5 \%$ & $5 \%$ & $42 \%$ & $6 \%$ \\
\hline \multicolumn{13}{|c|}{ URBAN-MEDIUM NET BUYER } \\
\hline Lowest $40 \%$ & $1 \%$ & $1 \%$ & $-1 \%$ & $0 \%$ & $1 \%$ & $9 \%$ & $-10 \%$ & $16 \%$ & $14 \%$ & $3 \%$ & $33 \%$ & $1 \%$ \\
\hline Middle 40\% & $1 \%$ & $1 \%$ & $1 \%$ & $2 \%$ & $0 \%$ & $16 \%$ & $-2 \%$ & $19 \%$ & $3 \%$ & $9 \%$ & $50 \%$ & $5 \%$ \\
\hline Top 20\% & $0 \%$ & $0 \%$ & $0 \%$ & $1 \%$ & $-3 \%$ & $17 \%$ & $-2 \%$ & $18 \%$ & $9 \%$ & $13 \%$ & $52 \%$ & $3 \%$ \\
\hline Total & $0 \%$ & $0 \%$ & $0 \%$ & $1 \%$ & $-1 \%$ & $16 \%$ & $-3 \%$ & $19 \%$ & $7 \%$ & $10 \%$ & $50 \%$ & $9 \%$ \\
\hline \multicolumn{13}{|c|}{ URBAN-LARGE NET BUYER } \\
\hline Lowest $40 \%$ & $0 \%$ & $3 \%$ & $0 \%$ & $12 \%$ & $0 \%$ & $40 \%$ & $0 \%$ & $18 \%$ & $15 \%$ & $23 \%$ & $110 \%$ & $1 \%$ \\
\hline Middle 40\% & $0 \%$ & $3 \%$ & $0 \%$ & $0 \%$ & $-3 \%$ & $44 \%$ & $1 \%$ & $9 \%$ & $10 \%$ & $15 \%$ & $79 \%$ & $1 \%$ \\
\hline Top 20\% & $0 \%$ & $6 \%$ & $0 \%$ & $12 \%$ & $-21 \%$ & $0 \%$ & $0 \%$ & $-21 \%$ & $63 \%$ & $104 \%$ & $143 \%$ & $0 \%$ \\
\hline Total & $0 \%$ & $3 \%$ & $0 \%$ & $8 \%$ & $-2 \%$ & $41 \%$ & $0 \%$ & $15 \%$ & $14 \%$ & $21 \%$ & $100 \%$ & $2 \%$ \\
\hline
\end{tabular}


Table A.6 Growth in Expenditure and Net Welfare

\begin{tabular}{rcc}
\multicolumn{1}{l}{ Households } & \% Change in real expenditure & \% Change in Net welfare \\
\hline All Vietnam & $33 \%$ & $26 \%$ \\
Rural & $35 \%$ & $28 \%$ \\
Urban & $28 \%$ & $22 \%$ \\
Seller-buyer category & & \\
Net buyer & $34 \%$ & $26 \%$ \\
Net seller & $32 \%$ & $24 \%$ \\
Net buying intensity & & \\
Marginal buyer & $22 \%$ & $30 \%$ \\
Medium Buyer & $39 \%$ & $25 \%$ \\
Large Buyer & $63 \%$ & $17 \%$ \\
Regions Northern Uplands & & \\
Red River Delta & $33 \%$ & $18 \%$ \\
North Central Coast & $41 \%$ & $1 \%$ \\
South Central Coast & $58 \%$ & $36 \%$ \\
Central Highlands & $21 \%$ & $57 \%$ \\
South East & $30 \%$ & $70 \%$ \\
Mekong Delta & $48 \%$ & $5 \%$ \\
\end{tabular}


Table A.7. Determinants of Household Income: Fixed Effects Dependent Variable: Logarithm of Real Household Income in 1998 prices

\begin{tabular}{lccc}
\hline & All & Rural & Urban \\
\cline { 1 - 4 } Demographics & & & \\
Household size (log) & 0.46 & 0.456 & 0.663 \\
Gender of HH Head $(1=$ male) & {$[0.056]^{* * *}$} & {$[0.059]^{* * *}$} & {$[0.136]^{* * *}$} \\
Age of HH Head & 0.15 & 0.094 & 0.251 \\
& {$[0.023]^{* * *}$} & {$[0.026]^{* * *}$} & {$[0.036]^{* * *}$} \\
& 0.022 & 0.021 & 0.024 \\
& {$[0.002]^{* * *}$} & {$[0.003]^{* * *}$} & {$[0.006]^{* * *}$}
\end{tabular}

Highest Diploma Obtained by HH Head (No diploma dummy is omitted)

Lower Secondary

$\begin{array}{lll}0.153 & 0.21 & -0.146\end{array}$

Upper Secondary

$[0.030]^{* * *} \quad[0.031]^{* * *} \quad[0.073]^{* *}$

$\begin{array}{lll}0.359 & 0.395 & 0.114\end{array}$

$[0.036]^{* * *} \quad[0.038]^{* * *} \quad[0.081]$

Technical Worker

$\begin{array}{lll}0.443 & 0.519 & 0.028\end{array}$

$[0.042]^{* * *} \quad[0.045]^{* * *} \quad[0.096]$

Vocational High

$\begin{array}{lll}0.324 & 0.393 & 0.048\end{array}$

$[0.062]^{* * *} \quad[0.071]^{* * *} \quad[0.103]$

Undergraduate

$\begin{array}{lll}0.314 & 0.455 & -0.129\end{array}$

$[0.074]^{* * *} \quad[0.084]^{* * *} \quad[0.102]$

Economic characteristics

Land size (log)

$\begin{array}{cc}0.025 & 0.025 \\ {[0.010]^{* * *}} & {[0.011]^{* *}}\end{array}$

Landless dummy (1= no land)

$-0.037$

[0.142]

Net seller dummy (1=net seller; $0=$ net buyer)

$\begin{array}{lll}0.047 & 0.014 & 0.899\end{array}$

$[0.038] \quad[0.039] \quad[0.200]^{* * *}$

Share of cash crop income

$\begin{array}{lll}0.278 & 0.26 & 0.924\end{array}$

Share of non-ag wages

$[0.077]^{* * *}$

$[0.079]^{* * *} \quad[0.296]^{* * *}$

$-0.152$

$-0.102$

$-0.53$

$[0.072]^{* *}$

[0.078]

$[0.122]^{* * *}$

Industry of HH Head Dummy (Agriculture

dummy omitted)

Manufacturing

$\begin{array}{lll}0.331 & 0.443 \quad 0.118\end{array}$

$[0.070]^{* * *} \quad[0.078]^{* * *} \quad[0.128]$

Other (Services etc.)

$\begin{array}{lll}0.389 & 0.367 & 0.206\end{array}$

$[0.049]^{* * *}[0.053]^{* * *} \quad[0.114]^{*}$

Regional Characteristics (Northern Uplands dummy omitted)

Urban dummy
Red River Delta
North Central Coast
South Central Coast

$-0.108$

[0.091]

0.378

[0.129]***

dropped

0.386

[0.127] $]^{* * *}$

dropped

dropped dropped

dropped dropped dropped 


\begin{tabular}{lccc}
\hline & All & Rural & Urban \\
\hline Central Highlands & dropped & dropped & dropped \\
South East & - & - & - \\
& dropped & dropped & \multicolumn{1}{c}{ dropped } \\
Mekong Delta & - & - & - \\
& dropped & dropped & \multicolumn{1}{c}{ dropped } \\
Constant & - & - & - \\
& 6.558 & 6.546 & 7.051 \\
Observations & $0.153]^{* * *}$ & {$[0.163]^{* * *}$} & {$[0.353]^{* * *}$} \\
Number of households & 6508 & 5572 & 1256 \\
R-squared & 3873 & 3256 & 795 \\
\hline
\end{tabular}

Notes: 1) Standard errors are in brackets.

2)* significant at $10 \%$; ** significant at $5 \%$; *** significant at $1 \%$.

Table A.8 Determinants of Income under Random Effects Specification Dependent Variable: Logarithm of Real Household Income, 1998 prices

\begin{tabular}{|c|c|c|c|}
\hline & All & Rural & Urban \\
\hline \multicolumn{4}{|l|}{ Demographics } \\
\hline \multirow[t]{2}{*}{ Household size (log) } & 0.753 & 0.724 & 0.726 \\
\hline & {$[0.024]^{* * *}$} & {$[0.026]^{* * *}$} & {$[0.058]^{* * *}$} \\
\hline \multirow{2}{*}{ Gender of HH Head (1=male) } & 0.148 & 0.096 & 0.248 \\
\hline & {$[0.019]^{* * *}$} & {$[0.022]^{* * *}$} & {$[0.031]^{* * *}$} \\
\hline \multirow[t]{2}{*}{ Age of HH Head } & 0.008 & 0.009 & 0.005 \\
\hline & {$[0.001]^{* * *}$} & {$[0.001]^{* * *}$} & {$[0.002]^{* * *}$} \\
\hline \multicolumn{4}{|l|}{$\begin{array}{l}\text { Highest Diploma Obtained by HH Head (No } \\
\text { diploma dummy is omitted) }\end{array}$} \\
\hline \multirow[t]{2}{*}{ Lower Secondary } & 0.129 & 0.198 & -0.205 \\
\hline & {$[0.023]^{* * *}$} & {$[0.024]^{* * *}$} & {$[0.057]^{* * *}$} \\
\hline \multirow[t]{2}{*}{ Upper Secondary } & 0.384 & 0.432 & 0.113 \\
\hline & {$[0.028]^{* * *}$} & {$[0.030]^{* * *}$} & {$[0.065]^{*}$} \\
\hline \multirow[t]{2}{*}{ Technical Worker } & 0.438 & 0.51 & 0.113 \\
\hline & {$[0.030]^{* * *}$} & {$[0.032]^{* * *}$} & {$[0.069]^{*}$} \\
\hline \multirow[t]{2}{*}{ Vocational High } & 0.432 & 0.498 & 0.183 \\
\hline & {$[0.044] * * *$} & {$[0.051]^{* * *}$} & {$[0.076]^{* *}$} \\
\hline \multirow[t]{2}{*}{ Undergraduate } & 0.418 & 0.504 & 0.119 \\
\hline & {$[0.054]^{* * *}$} & {$[0.062]^{* * *}$} & [0.084] \\
\hline \multicolumn{4}{|l|}{ Economic characteristics } \\
\hline \multirow[t]{2}{*}{ Land size (log) } & -0.009 & 0.013 & \\
\hline & {$[0.005]^{* *}$} & {$[0.006]^{* *}$} & \\
\hline \multirow[t]{2}{*}{ Landless dummy (1= no land) } & & & 0.312 \\
\hline & & & {$[0.072]^{* * *}$} \\
\hline \multirow[t]{2}{*}{ Net seller dummy ( $1=$ net seller; $0=$ net buyer) } & 0.098 & 0.083 & 0.053 \\
\hline & {$[0.022] * * *$} & {$[0.023]^{* * *}$} & [0.098] \\
\hline \multirow[t]{2}{*}{ Share of cash crop income } & 0.376 & 0.357 & 0.552 \\
\hline & {$[0.052]^{* * *}$} & {$[0.053]^{* * *}$} & {$[0.185]^{* * *}$} \\
\hline \multirow[t]{2}{*}{ Share of non-ag wages } & -0.229 & -0.106 & -0.56 \\
\hline & {$[0.044]^{* * *}$} & {$[0.051]^{* *}$} & {$[0.072]^{* * *}$} \\
\hline
\end{tabular}




\begin{tabular}{lccc}
\hline & All & Rural & Urban \\
\hline $\begin{array}{l}\text { Industry of HH Head Dummy (Agriculture } \\
\text { dummy omitted) }\end{array}$ & & & \\
Manufacturing & 0.387 & 0.424 & 0.327 \\
& {$[0.042]^{* * *}$} & {$[0.049]^{* * *}$} & {$[0.079]^{* * *}$} \\
Other (Services etc.) & 0.486 & 0.437 & 0.427 \\
& {$[0.030]^{* * *}$} & {$[0.032]^{* * *}$} & {$[0.067]^{* * *}$} \\
& & & \\
Regional Characteristics (Northern Uplands & & & \\
dummy omitted) & & & \\
\hline Urban dummy & 0.272 & & \\
& {$[0.035]^{* * *}$} & & \\
Red River Delta & 0.142 & 0.116 & 0.254 \\
& {$[0.033]^{* * *}$} & {$[0.034]^{* * *}$} & {$[0.090]^{* * *}$} \\
North Central Coast & -0.109 & 0.055 & 0.138 \\
& {$[0.036]^{* * *}$} & {$[0.037]^{* * *}$} & {$[0.112]$} \\
South Central Coast & 0.054 & -0.121 & 0.12 \\
& {$[0.041]$} & {$[0.044]$} & {$[0.097]$} \\
Central Highlands & 0.262 & 0.266 & \\
& {$[0.072]^{* * *}$} & {$[0.071]^{* * *}$} & \\
South East & 0.432 & 0.393 & 0.65 \\
& {$[0.044]^{* * *}$} & {$[0.048]^{* * *}$} & {$[0.100]^{* * *}$} \\
Mekong Delta & 0.298 & 0.326 & 0.279 \\
& {$[0.035]^{* * *}$} & {$[0.037]^{* * *}$} & {$[0.094]^{* * *}$} \\
Constant & 6.834 & 6.707 & 7.18 \\
& {$[0.071]^{* * *}$} & {$[0.076]^{* * *}$} & {$[0.160]^{* * *}$} \\
Observations & 6508 & 5572 & 1256 \\
Number of households & 3873 & 3256 & 795 \\
\hline Not 1 Stan & & &
\end{tabular}

Notes: 1) Standard errors are in brackets.

$2)^{*}$ significant at $10 \%$; ** significant at $5 \%$; *** significant at $1 \%$.

Table A.9. OLS Regression: Changes in Income-RURAL Dependent variable: Growth in Income (Log Income98 - Log Income93)

\begin{tabular}{|c|c|c|c|c|c|c|}
\hline & Model 1 & Model 2 & Model 3 & Model 4 & Model 5 & Full Model \\
\hline \multicolumn{7}{|l|}{ Initial Characteristics } \\
\hline \multicolumn{7}{|l|}{ Demographics } \\
\hline \multirow[t]{2}{*}{ Household size (log) } & 0.06 & 0.06 & 0.07 & 0.06 & 0.04 & 0.05 \\
\hline & {$[0.052]$} & {$[0.051]$} & [0.052] & {$[0.052]$} & [0.053] & {$[0.053]$} \\
\hline \multirow[t]{2}{*}{ Age of HH Head } & 0.00 & 0.00 & 0.00 & 0.00 & 0.00 & 0.00 \\
\hline & {$[0.002]$} & [0.002] & [0.002] & [0.002] & [0.002] & [0.002] \\
\hline \multirow[t]{2}{*}{ Gender of HH Head (1=male) } & 0.01 & 0.01 & 0.00 & 0.00 & 0.01 & 0.01 \\
\hline & [0.048] & [0.048] & [0.048] & {$[0.048]$} & [0.048] & [0.049] \\
\hline \multicolumn{7}{|c|}{$\begin{array}{l}\text { Highest Diploma Obtained by HH Head (No } \\
\text { diploma dummy is omitted) }\end{array}$} \\
\hline \multirow[t]{2}{*}{ Lower Secondary } & 0.10 & 0.10 & 0.10 & 0.09 & 0.09 & 0.09 \\
\hline & {$[0.046]^{* *}$} & {$[0.046]^{* *}$} & {$[0.046]^{* *}$} & {$[0.047]^{* *}$} & {$[0.047]^{*}$} & {$[0.047]^{*}$} \\
\hline \multirow[t]{2}{*}{ Upper Secondary } & 0.10 & 0.10 & 0.10 & 0.10 & 0.10 & 0.10 \\
\hline & {$[0.070]$} & {$[0.070]$} & {$[0.070]$} & {$[0.070]$} & [0.069] & [0.069] \\
\hline \multirow[t]{2}{*}{ Technical Worker } & -0.02 & -0.01 & -0.02 & -0.02 & -0.02 & -0.01 \\
\hline & [0.090] & [0.090] & [0.091] & [0.091] & [0.090] & [0.090] \\
\hline Vocational High & -0.02 & -0.02 & -0.01 & -0.01 & -0.03 & -0.03 \\
\hline
\end{tabular}




\begin{tabular}{|c|c|c|c|c|c|c|}
\hline & Model 1 & Model 2 & Model 3 & Model 4 & Model 5 & Full Model \\
\hline \multirow{3}{*}{ Undergraduate } & [0.092] & [0.092] & [0.092] & [0.092] & [0.092] & [0.092] \\
\hline & 0.37 & 0.37 & 0.37 & 0.39 & 0.34 & 0.34 \\
\hline & {$[0.171]^{* *}$} & {$[0.171]^{* *}$} & {$[0.170]^{* *}$} & {$[0.166]^{* *}$} & {$[0.173]^{*}$} & {$[0.175]^{*}$} \\
\hline \multicolumn{7}{|l|}{$\begin{array}{l}\text { Regional Characteristics (Northern Uplands } \\
\text { dummy omitted) }\end{array}$} \\
\hline \multirow[t]{2}{*}{ Red River Delta } & -0.07 & -0.07 & -0.07 & -0.09 & -0.10 & -0.11 \\
\hline & {$[0.101]$} & {$[0.101]$} & {$[0.100]$} & [0.099] & {$[0.098]$} & {$[0.098]$} \\
\hline \multirow[t]{2}{*}{ North Central Coast } & 0.37 & 0.37 & 0.37 & 0.39 & 0.35 & 0.33 \\
\hline & {$[0.097]^{* * *}$} & {$[0.101]^{* * *}$} & {$[0.096]^{* * *}$} & {$[0.100]^{* * *}$} & {$[0.095]^{* * *}$} & {$[0.100]^{* * *}$} \\
\hline \multirow[t]{2}{*}{ South Central Coast } & 0.39 & 0.39 & 0.39 & 0.36 & 0.35 & 0.35 \\
\hline & {$[0.101]^{* * *}$} & {$[0.097]^{* * *}$} & {$[0.100]^{* * *}$} & {$[0.095]^{* * *}$} & {$[0.100]^{* * *}$} & {$[0.094]^{* * *}$} \\
\hline \multirow{2}{*}{ Central Highlands } & 0.27 & 0.28 & 0.30 & 0.27 & 0.24 & 0.25 \\
\hline & [0.257] & [0.302] & [0.313] & {$[0.310]$} & [0.307] & [0.306] \\
\hline \multirow[t]{2}{*}{ South East } & 0.55 & 0.55 & 0.55 & 0.52 & 0.49 & 0.48 \\
\hline & {$[0.112]^{* * *}$} & {$[0.115]^{* * *}$} & {$[0.119] * * *$} & {$[0.120]^{* * *}$} & {$[0.115]^{* * *}$} & {$[0.116]^{* * *}$} \\
\hline \multirow[t]{2}{*}{ Mekong Delta } & 0.31 & 0.31 & 0.30 & 0.29 & 0.29 & 0.27 \\
\hline & {$[0.116]^{* * *}$} & {$[0.116]^{* * *}$} & {$[0.116]^{* *}$} & {$[0.116]^{* *}$} & {$[0.113]^{* *}$} & {$[0.115]^{* *}$} \\
\hline \multicolumn{7}{|l|}{ Economic characteristics } \\
\hline \multicolumn{7}{|l|}{ Log of Real Income (For Convergence) } \\
\hline \multirow[t]{2}{*}{ Land size (log) } & 0.00 & 0.00 & 0.00 & 0.01 & 0.02 & 0.01 \\
\hline & [0.019] & [0.019] & [0.019] & [0.019] & [0.019] & [0.019] \\
\hline \multirow[t]{2}{*}{ Net seller dummy ( $1=$ net seller; $0=$ net buyer) } & -0.01 & -0.01 & -0.01 & -0.01 & 0.00 & 0.04 \\
\hline & [0.053] & [0.052] & [0.052] & [0.051] & [0.051] & [0.065] \\
\hline \multirow[t]{2}{*}{ Share of cash crop income } & -0.23 & -0.25 & -0.28 & -0.24 & -0.19 & -0.17 \\
\hline & [0.265] & [0.296] & [0.306] & [0.303] & [0.298] & [0.303] \\
\hline \multirow[t]{2}{*}{ Share of food crop income } & 0.61 & 0.61 & 0.72 & 0.73 & 0.74 & 0.75 \\
\hline & {$[0.217]^{* * *}$} & {$[0.218]^{* * *}$} & {$[0.309]^{* *}$} & {$[0.305]^{* *}$} & {$[0.304]^{* *}$} & {$[0.302]^{* *}$} \\
\hline \multirow[t]{2}{*}{ Share of non-farm business income } & -0.02 & -0.02 & -0.01 & 0.18 & 0.26 & 0.27 \\
\hline & [0.145] & [0.145] & [0.145] & {$[0.156]$} & [0.156] & {$[0.157]^{*}$} \\
\hline \multirow[t]{2}{*}{ Share of non-ag wages } & 0.19 & 0.19 & 0.20 & 0.19 & 0.54 & 0.55 \\
\hline & {$[0.179]$} & {$[0.179]$} & {$[0.179]$} & {$[0.181]$} & {$[0.184]^{* * *}$} & {$[0.184]^{* * *}$} \\
\hline \multicolumn{7}{|l|}{$\begin{array}{l}\text { Industry of HH Head Dummy (Agriculture } \\
\text { dummy omitted) }\end{array}$} \\
\hline \multirow[t]{2}{*}{ Manufacturing } & -0.11 & -0.11 & -0.12 & -0.14 & -0.17 & -0.17 \\
\hline & [0.104] & [0.104] & [0.104] & [0.101] & {$[0.098]^{*}$} & {$[0.097]^{*}$} \\
\hline \multirow[t]{2}{*}{ Other (Services etc.) } & -0.12 & -0.12 & -0.13 & -0.14 & -0.17 & -0.17 \\
\hline & {$[0.069]^{*}$} & {$[0.069]^{*}$} & {$[0.069]^{*}$} & {$[0.068]^{* *}$} & {$[0.068]^{* *}$} & {$[0.069]^{* *}$} \\
\hline \multicolumn{7}{|l|}{ Difference Variables } \\
\hline \multirow[t]{2}{*}{ Growth in Household Size } & 0.60 & 0.60 & 0.60 & 0.59 & 0.57 & 0.57 \\
\hline & {$[0.070]^{* * *}$} & {$[0.070]^{* * *}$} & {$[0.070] * * *$} & {$[0.069]^{* * *}$} & {$[0.068]^{* * *}$} & {$[0.068]^{* * *}$} \\
\hline \multirow[t]{2}{*}{ Delta Age of HH Head } & 0.00 & 0.00 & 0.00 & 0.00 & 0.00 & 0.00 \\
\hline & [0.003] & [0.003] & [0.003] & [0.003] & [0.003] & {$[0.003]$} \\
\hline Growth in Land size & 0.02 & 0.02 & 0.02 & 0.02 & 0.03 & 0.03 \\
\hline & {$[0.013]$} & {$[0.012]^{*}$} & {$[0.012]$} & {$[0.012]^{* *}$} & {$[0.012]^{* *}$} & {$[0.013]^{*}$} \\
\hline Change in share of cash crop income & & -0.03 & -0.06 & -0.02 & 0.03 & 0.05 \\
\hline & & [0.262] & [0.272] & [0.269] & [0.273] & [0.277] \\
\hline Change in share of food crop income & & & 0.15 & 0.15 & 0.16 & 0.17 \\
\hline & & & {$[0.256]$} & {$[0.248]$} & [0.245] & {$[0.243]$} \\
\hline Change in share of business income & & & & 0.29 & 0.37 & 0.38 \\
\hline
\end{tabular}




\begin{tabular}{|c|c|c|c|c|c|c|}
\hline & Model 1 & Model 2 & Model 3 & Model 4 & Model 5 & Full Model \\
\hline & & & & {$[0.120]^{* *}$} & {$[0.131]^{* * *}$} & {$[0.131]^{* * *}$} \\
\hline \multirow{2}{*}{ Change in share of non-ag wage income } & & & & & 0.41 & 0.42 \\
\hline & & & & & {$[0.128]^{* * *}$} & {$[0.128]^{* * *}$} \\
\hline \multirow[t]{2}{*}{ Change in the net selling position } & & & & & & 0.07 \\
\hline & & & & & & [0.045] \\
\hline \multirow[t]{2}{*}{ Constant } & 0.35 & 0.38 & 0.38 & 0.32 & 0.31 & 0.32 \\
\hline & {$[0.146]^{* *}$} & {$[0.145]^{* * *}$} & {$[0.145]^{* * *}$} & {$[0.143]^{* *}$} & {$[0.155]^{* *}$} & {$[0.155]^{* *}$} \\
\hline Observations & 2994.00 & 2994.00 & 2994.00 & 2994.00 & 2994.00 & 2993.00 \\
\hline R-squared & 0.12 & 0.13 & 0.14 & 0.15 & 0.15 & 0.15 \\
\hline
\end{tabular}

Notes: 1) Cluster corrected standard errors are in brackets.

$2)^{*}$ significant at $10 \%$; ** significant at 5\%; *** significant at $1 \%$.

Table A.10. OLS Regression: Changes in Income-URBAN Dependent variable: Growth in Income (Log Income98 - Log Income93)

\begin{tabular}{|c|c|c|c|c|c|c|}
\hline & Model 1 & Model 2 & Model 3 & Model 4 & Model 5 & Full Model \\
\hline \multicolumn{7}{|l|}{ Initial Characteristics } \\
\hline \multicolumn{7}{|l|}{ Demographics } \\
\hline \multirow[t]{2}{*}{ Household size (log) } & 0.16 & 0.158 & 0.142 & 0.134 & 0.147 & 0.17 \\
\hline & [0.129] & {$[0.130]$} & [0.137] & [0.139] & [0.141] & [0.134] \\
\hline \multirow[t]{2}{*}{ Age of HH Head } & -0.002 & -0.002 & -0.002 & -0.001 & -0.003 & -0.002 \\
\hline & [0.004] & {$[0.004]$} & {$[0.004]$} & [0.004] & [0.004] & {$[0.004]$} \\
\hline \multirow[t]{2}{*}{ Gender of HH Head (1=male) } & -0.009 & -0.01 & -0.032 & -0.044 & -0.033 & -0.055 \\
\hline & {$[0.086]$} & {$[0.089]$} & {$[0.086]$} & {$[0.083]$} & {$[0.079]$} & {$[0.070]$} \\
\hline \multicolumn{7}{|c|}{$\begin{array}{l}\text { Highest Diploma Obtained by HH Head (No } \\
\text { diploma dummy is omitted) }\end{array}$} \\
\hline \multirow[t]{2}{*}{ Lower Secondary } & 0.36 & 0.33 & 0.33 & 0.33 & 0.31 & 0.33 \\
\hline & {$[0.107]^{* * *}$} & {$[0.107]^{* * *}$} & {$[0.105]^{* * *}$} & {$[0.104]^{* * *}$} & {$[0.101]^{* * *}$} & {$[0.095]^{* * *}$} \\
\hline \multirow[t]{2}{*}{ Upper Secondary } & 0.13 & 0.16 & 0.15 & 0.16 & 0.11 & 0.16 \\
\hline & {$[0.214]$} & {$[0.228]$} & {$[0.228]$} & {$[0.230]$} & [0.227] & [0.229] \\
\hline \multirow[t]{2}{*}{ Technical Worker } & -0.05 & -0.04 & -0.04 & -0.03 & -0.04 & 0.01 \\
\hline & [0.137] & [0.139] & [0.134] & [0.126] & [0.119] & [0.111] \\
\hline \multirow[t]{2}{*}{ Vocational High } & 0.12 & 0.12 & 0.09 & 0.12 & 0.13 & 0.15 \\
\hline & [0.141] & [0.140] & [0.146] & [0.142] & [0.134] & [0.130] \\
\hline \multirow[t]{2}{*}{ Undergraduate } & -0.07 & -0.09 & -0.09 & -0.07 & -0.08 & -0.03 \\
\hline & [0.253] & [0.247] & {$[0.248]$} & [0.242] & [0.240] & [0.233] \\
\hline \multicolumn{7}{|c|}{$\begin{array}{l}\text { Regional Characteristics (Northern Uplands } \\
\text { dummy omitted) }\end{array}$} \\
\hline \multirow[t]{2}{*}{ Red River Delta } & -0.577 & -0.575 & -0.587 & -0.585 & -0.573 & -0.614 \\
\hline & {$[0.137] * * *$} & {$[0.137]^{* * *}$} & {$[0.133]^{* * *}$} & {$[0.137]^{* * *}$} & {$[0.128]^{* * *}$} & {$[0.116]^{* * *}$} \\
\hline \multirow[t]{2}{*}{ North Central Coast } & 0.164 & 0.215 & 0.172 & 0.163 & 0.246 & 0.176 \\
\hline & {$[0.187]$} & {$[0.200]$} & [0.197] & [0.193] & [0.165] & {$[0.221]$} \\
\hline \multirow[t]{2}{*}{ South Central Coast } & 0.19 & 0.209 & 0.175 & 0.171 & 0.204 & 0.159 \\
\hline & [0.179] & [0.183] & [0.176] & [0.168] & [0.211] & {$[0.210]$} \\
\hline \multirow[t]{2}{*}{ Central Highlands } & 0 & 0 & 0 & 0 & 0 & 0 \\
\hline & {$[0.000]$} & {$[0.000]$} & {$[0.000]$} & {$[0.000]$} & {$[0.000]$} & {$[0.000]$} \\
\hline \multirow[t]{2}{*}{ South East } & 0.044 & 0.062 & 0.036 & 0.034 & 0.067 & 0.028 \\
\hline & [0.175] & [0.180] & [0.175] & [0.177] & [0.162] & [0.150] \\
\hline \multirow[t]{2}{*}{ Mekong Delta } & 0.112 & 0.106 & 0.081 & 0.075 & 0.053 & -0.008 \\
\hline & [0.206] & [0.206] & [0.202] & [0.199] & [0.200] & [0.186] \\
\hline
\end{tabular}




\begin{tabular}{|c|c|c|c|c|c|c|}
\hline & Model 1 & Model 2 & Model 3 & Model 4 & Model 5 & Full Model \\
\hline \multicolumn{7}{|l|}{ Economic characteristics } \\
\hline \multicolumn{7}{|l|}{ Log of Real Income (For Convergence) } \\
\hline \multirow[t]{2}{*}{ Land size (log) } & -0.041 & -0.043 & -0.037 & -0.035 & -0.041 & -0.055 \\
\hline & {$[0.023]^{*}$} & {$[0.023]^{*}$} & {$[0.024]$} & {$[0.025]$} & {$[0.025]$} & {$[0.022] * *$} \\
\hline \multirow[t]{2}{*}{ Net seller dummy ( $1=$ net seller; $0=$ net buyer) } & -0.057 & -0.059 & -0.078 & -0.076 & -0.061 & 0.21 \\
\hline & [0.139] & [0.141] & [0.143] & [0.142] & [0.136] & [0.151] \\
\hline \multirow[t]{2}{*}{ Share of cash crop income } & 0.33 & 0.345 & 0.483 & 0.426 & 0.465 & 0.589 \\
\hline & [0.870] & [0.647] & [0.558] & [0.585] & [0.589] & [0.582] \\
\hline \multirow[t]{2}{*}{ Share of food crop income } & 1.034 & 1.023 & 0.296 & 0.381 & 0.268 & 0.396 \\
\hline & [0.883] & [0.919] & [0.714] & [0.685] & [0.661] & [0.713] \\
\hline \multirow[t]{2}{*}{ Share of non-farm business income } & -0.283 & -0.28 & -0.283 & -0.17 & -0.282 & -0.254 \\
\hline & [0.301] & [0.305] & [0.305] & [0.313] & [0.294] & [0.305] \\
\hline \multirow[t]{2}{*}{ Share of non-ag wages } & 0.049 & 0.033 & 0.033 & 0.043 & -0.204 & -0.17 \\
\hline & {$[0.267]$} & {$[0.262]$} & {$[0.263]$} & {$[0.261]$} & {$[0.252]$} & {$[0.255]$} \\
\hline \multicolumn{7}{|l|}{ Difference Variables } \\
\hline \multirow[t]{2}{*}{ Growth in Household Size } & 0.619 & 0.621 & 0.6 & 0.594 & 0.666 & 0.676 \\
\hline & {$[0.155]^{* * *}$} & {$[0.160]^{* * *}$} & {$[0.154]^{* * *}$} & {$[0.159]^{* * *}$} & {$[0.178]^{* * *}$} & {$[0.181]^{* * *}$} \\
\hline \multirow[t]{2}{*}{ Change in Age of HH Head } & 0.005 & 0.005 & 0.006 & 0.007 & 0.005 & 0.007 \\
\hline & [0.007] & [0.007] & [0.007] & [0.007] & [0.007] & [0.006] \\
\hline \multirow[t]{2}{*}{ Growth in Land size } & -0.009 & -0.011 & -0.005 & -0.001 & -0.009 & -0.021 \\
\hline & [0.016] & [0.015] & [0.016] & [0.017] & [0.017] & [0.017] \\
\hline \multirow[t]{2}{*}{ Change in share of cash crop income } & & 0.501 & 0.486 & 0.531 & 0.475 & 0.523 \\
\hline & & [0.337] & [0.314] & {$[0.307]^{*}$} & [0.311] & [0.304]* \\
\hline \multirow[t]{2}{*}{ Change in share of food crop income } & & & -0.901 & -0.819 & -0.967 & -0.766 \\
\hline & & & {$[0.491]^{*}$} & [0.496] & {$[0.512]^{*}$} & [0.513] \\
\hline \multirow[t]{2}{*}{ Change in share of business income } & & & & 0.169 & -0.018 & 0.036 \\
\hline & & & & [0.188] & {$[0.230]$} & {$[0.235]$} \\
\hline \multirow[t]{2}{*}{ Change in share of non-ag wage income } & & & & & -0.479 & -0.427 \\
\hline & & & & & {$[0.253]^{*}$} & [0.258] \\
\hline \multirow[t]{2}{*}{ Change in the net selling position } & & & & & & 0.483 \\
\hline & & & & & & {$[0.219]^{* *}$} \\
\hline \multirow[t]{2}{*}{ Constant } & 0.526 & 0.538 & 0.599 & 0.525 & 0.688 & 0.623 \\
\hline & {$[0.393]$} & {$[0.375]$} & [0.379] & [0.371] & {$[0.366]^{*}$} & [0.369] \\
\hline Observations & 319 & 319 & 319 & 319 & 319 & 319 \\
\hline R-squared & 0.22 & 0.23 & 0.23 & 0.23 & 0.25 & 0.26 \\
\hline
\end{tabular}

Notes: 1) Cluster corrected standard errors are in brackets.

$2)^{*}$ significant at $10 \%$; ** significant at 5\%; *** significant at $1 \%$. 


\section{Appendix 2}

In order to find out the characteristics that contribute to being a net buyer, we run a Probit regression for each year. Formally, we estimate:

$$
N B_{h, t}=\phi_{t}+\gamma_{t} X_{h, t}+\eta_{h, t}
$$

for $t=1993$, 1998. The dependent variable (NB) is dichotomous which takes a value of 1 if the household is a net buyer of rice and 0 if the household is a net seller ${ }^{25}$. The independent variables $\left(X_{h, t}\right)$ are: demographic characteristics of the household head that might be of relevance (gender, age education level), locational characteristics (region, urban-rural), economic household characteristics (share of cash crop income, share of non agricultural wages) as they relate to assets and income structure, and income (logarithm of total income). We run a separate regression for each year, and report the results in Tables A.11 and A.12 respectively. Results are slightly different for 1993 and 1998. In both years, living in an urban area increases probability of being a net buyer by $27 \%$ (16\% in 1998). Furthermore, larger households, households with higher share of cash crop income and other wages, and households who do not own any land are more likely to be net buyers. The biggest marginal effect comes from share of cash crop income and having no land for both years. Households residing in Mekong and Red River Deltas are less likely to be net buyers, which is intuitive since these regions make up about 60\% of all rice production. In 1993 households in living in Central Highlands are more likely to be net buyers compared to the Northern Uplands households, while in 1998 it is just the reverse. For households with higher incomes, it is less likely that they are net buyers if they live in rural areas. For the urban areas the households with agriculture as their main industry are less likely to be net buyers, compared to households in other industries (services etc.)

\footnotetext{
${ }^{25}$ A handful of households who are neither net sellers nor net buyers are automatically excluded from the regression. Hence we can analyze this regression as the determinants of both net buyers and net sellers.
} 
Table A.11 Determinants of Net Buyers in 1993 (PROBIT) Dependent Variable: net buyer of rice dummy=1 if household is a net buyer ( 0 if net seller)

\begin{tabular}{|c|c|c|c|}
\hline & All & Rural & Urban \\
\hline \multicolumn{4}{|l|}{ Demographics } \\
\hline \multirow[t]{2}{*}{ Household size } & 0.021 & 0.043 & 0.00048 \\
\hline & {$[0.00524] * * *$} & {$[0.00652] * * *$} & {$[0.00110]$} \\
\hline \multirow[t]{2}{*}{ Gender of HH Head (1=male) } & -0.02036 & 0.00883 & -0.00042 \\
\hline & {$[0.02476]$} & {$[0.02995]$} & {$[0.00432]$} \\
\hline \multirow[t]{2}{*}{ Age of HH Head } & 0.0013 & 0.0017 & -0.00007 \\
\hline & {$[0.00077]^{*}$} & {$[0.00088]^{*}$} & [0.00019] \\
\hline \multirow{2}{*}{\multicolumn{4}{|c|}{$\begin{array}{l}\text { Highest Diploma Obtained by } \mathrm{HH} \\
\text { Head (No diploma dummy is } \\
\text { omitted) }\end{array}$}} \\
\hline & & & \\
\hline \multirow[t]{2}{*}{ Primary } & -0.04141 & -0.04923 & -0.00865 \\
\hline & {$[0.02588]$} & [0.02929]* & {$[0.00952]$} \\
\hline \multirow[t]{2}{*}{ Lower Secondary } & -0.01874 & -0.01694 & -0.01294 \\
\hline & {$[0.02836]$} & {$[0.03228]$} & {$[0.01445]$} \\
\hline \multirow[t]{2}{*}{ Upper Secondary } & -0.01262 & -0.02994 & \\
\hline & [0.04638] & {$[0.05229]$} & \\
\hline \multirow[t]{2}{*}{ Technical Worker } & 0.10226 & 0.09703 & \\
\hline & {$[0.03877]^{* * *}$} & {$[0.05421]^{*}$} & \\
\hline \multirow[t]{2}{*}{ Vocational High } & 0.14957 & 0.15866 & \\
\hline & {$[0.03791]^{* * *}$} & {$[0.05698]^{* * *}$} & \\
\hline \multirow[t]{2}{*}{ Undergraduate } & 0.24138 & 0.26661 & \\
\hline & {$[0.04901]^{* * *}$} & {$[0.10313] * * *$} & \\
\hline \multicolumn{4}{|l|}{ Economic characteristics } \\
\hline \multirow[t]{2}{*}{ Landless dummy (1= no land) } & 0.47592 & & \\
\hline & {$[0.01369]^{* * *}$} & & \\
\hline \multirow[t]{2}{*}{ Land size (log) } & & -0.13176 & \\
\hline & & {$[0.01752] * * *$} & \\
\hline \multirow[t]{2}{*}{ Real Total Income (log) } & -0.05335 & -0.04593 & 0.00238 \\
\hline & {$[0.01241]^{* * *}$} & {$[0.01478]^{* * *}$} & {$[0.00140]$} \\
\hline \multirow[t]{2}{*}{ Share of cash crop income } & 0.48025 & 0.59573 & 0.02272 \\
\hline & {$[0.12559]^{* * *}$} & {$[0.17158]^{* * *}$} & {$[0.02845]$} \\
\hline \multirow[t]{2}{*}{ Share of non-agricultural wages } & 0.13008 & 0.14804 & 0.00527 \\
\hline & {$[0.04558]^{* * *}$} & {$[0.05732]^{* * *}$} & {$[0.00976]$} \\
\hline \multicolumn{4}{|c|}{$\begin{array}{l}\text { Industry of HH Head Dummy (Other } \\
\text { Industry dummy omitted) }\end{array}$} \\
\hline \multirow[t]{2}{*}{ Agriculture } & -0.10707 & -0.05506 & -0.04036 \\
\hline & {$[0.02871] * * *$} & {$[0.03755]$} & {$[0.02659]^{* * *}$} \\
\hline \multirow[t]{2}{*}{ Manufacturing } & 0.00975 & -0.02185 & -0.00344 \\
\hline & {$[0.04927]$} & {$[0.05951]$} & {$[0.01105]$} \\
\hline \multirow{2}{*}{\multicolumn{4}{|c|}{$\begin{array}{l}\text { Regional Characteristics (Northern } \\
\text { Uplands dummy omitted) }\end{array}$}} \\
\hline & & & \\
\hline \multirow[t]{2}{*}{ Urban dummy } & 0.27636 & & \\
\hline & {$[0.02500] * * *$} & & \\
\hline \multirow[t]{2}{*}{ Red River Delta } & -0.25503 & -0.26594 & \\
\hline & {$[0.02940] * * *$} & {$[0.02817]^{* * *}$} & \\
\hline \multirow[t]{2}{*}{ North Central Coast } & -0.13769 & -0.14337 & -0.99442 \\
\hline & {$[0.03165] * * *$} & {$[0.03223] * * *$} & {$[0.13518]^{* * *}$} \\
\hline
\end{tabular}




\begin{tabular}{lccc} 
& All & Rural & Urban \\
Central Highlands & {$[0.03972]^{* * *}$} & {$[0.03866]^{* * *}$} & {$[0.01284]^{* * *}$} \\
South East & 0.2111 & 0.28874 & \\
& {$[0.04773]^{* * *}$} & {$[0.07727]^{* * *}$} & \\
Mekong Delta & -0.0583 & -0.01896 & \\
& {$[0.04480]$} & {$[0.05177]$} & \\
Observations & -0.33181 & -0.2478 & -0.93467 \\
Pseudo R2 & {$[0.03208]^{* * *}$} & {$[0.03102]^{* * *}$} & {$[0.07018]^{* * *}$} \\
\hline
\end{tabular}

Notes: 1) The regression is presented in the marginal effect format. The coefficients reflect the marginal effect of changes in the respective independent variable. For dummy variables the marginal effect is for the discrete change of dummy variable from 0 to 1 .

2) Robust standard errors are in brackets

$3)^{*}$ significant at $10 \%$; ** significant at $5 \%$; ** significant at $1 \%$

Table A.12. Determinants of Net Buyers in 1998 (PROBIT) Dependent Variable: net buyer of rice dummy=1 if household is a net buyer ( 0 if net seller)

\begin{tabular}{|c|c|c|c|}
\hline & All & Rural & Urban \\
\hline \multicolumn{4}{|l|}{ Demographics } \\
\hline \multirow[t]{2}{*}{ Household size } & 0.025 & 0.05 & 0.00002 \\
\hline & {$[0.005]^{* * *}$} & {$[0.007]^{* * *}$} & {$[0.00017]$} \\
\hline \multirow[t]{2}{*}{ Gender of HH Head (1=male) } & 0.068 & 0.053 & 0.001 \\
\hline & {$[0.023]^{* * *}$} & {$[0.028] *$} & [0.00087] \\
\hline \multirow[t]{2}{*}{ Age of HH Head } & 0.001 & 0.001 & 0.00002 \\
\hline & {$[0.001]$} & {$[0.001]$} & {$[0.00003]$} \\
\hline \multicolumn{4}{|l|}{$\begin{array}{l}\text { Highest Diploma Obtained by HH } \\
\text { Head (No diploma dummy is } \\
\text { omitted) }\end{array}$} \\
\hline \multirow[t]{2}{*}{ Lower Secondary } & -0.128 & -0.153 & -0.00169 \\
\hline & {$[0.039]^{* * *}$} & {$[0.043]^{* * *}$} & {$[0.00389]$} \\
\hline \multirow[t]{2}{*}{ Upper Secondary } & -0.127 & -0.158 & -0.00299 \\
\hline & {$[0.042]^{* * *}$} & {$[0.046]^{* * *}$} & [0.00625] \\
\hline \multirow[t]{2}{*}{ Technical Worker } & -0.147 & -0.179 & 0.0005 \\
\hline & {$[0.044]^{* * *}$} & {$[0.047]^{* * *}$} & [0.00109] \\
\hline \multirow[t]{2}{*}{ Vocational High } & -0.064 & -0.095 & 0.0004 \\
\hline & {$[0.058]$} & {$[0.066]$} & [0.00113] \\
\hline \multirow[t]{2}{*}{ Undergraduate } & -0.093 & -0.102 & -0.00126 \\
\hline & [0.059] & {$[0.065]$} & {$[0.00534]$} \\
\hline \multirow[t]{2}{*}{ Masters } & -0.063 & -0.082 & -0.0001 \\
\hline & [0.054] & [0.062] & {$[0.00202]$} \\
\hline \multirow[t]{2}{*}{ Doctorate } & 0.001 & -0.045 & 0.00069 \\
\hline & {$[0.091]$} & [0.118] & {$[0.00090]$} \\
\hline \multicolumn{4}{|l|}{ Economic characteristics } \\
\hline \multirow[t]{2}{*}{ Landless dummy (1= no land) } & 0.449 & & 0.0318 \\
\hline & {$[0.012]^{* * *}$} & & {$[0.01884]^{* * *}$} \\
\hline \multirow[t]{2}{*}{ Land size (log) } & & -0.153 & \\
\hline & & {$[0.015]^{* * *}$} & \\
\hline \multirow[t]{2}{*}{ Real Total Income (log) } & -0.053 & -0.043 & 0.00045 \\
\hline & {$[0.012]^{* * *}$} & {$[0.016]^{* * *}$} & {$[0.00048]$} \\
\hline Share of cash crop income & 0.58 & 0.889 & 0.00044 \\
\hline
\end{tabular}




\begin{tabular}{|c|c|c|c|}
\hline & All & Rural & Urban \\
\hline & {$[0.080]^{* * *}$} & {$[0.118]^{* * *}$} & {$[0.00244]$} \\
\hline Share of non-ag wages & $\begin{array}{c}0.115 \\
{[0.049]^{* *}}\end{array}$ & $\begin{array}{c}0.104 \\
{[0.062]^{*}}\end{array}$ & $\begin{array}{c}0.00027 \\
{[0.00093]}\end{array}$ \\
\hline \multicolumn{4}{|c|}{$\begin{array}{l}\text { Industry of HH Head Dummy } \\
\text { (Other industry dummy omitted) }\end{array}$} \\
\hline Agriculture & $\begin{array}{c}-0.16 \\
{[0.023]^{* * *}}\end{array}$ & $\begin{array}{c}-0.127 \\
{[0.031]^{* * *}}\end{array}$ & $\begin{array}{c}-0.00804 \\
{[0.00836]^{* * *}}\end{array}$ \\
\hline Manufacturing & $\begin{array}{l}-0.038 \\
{[0.046]}\end{array}$ & $\begin{array}{l}-0.073 \\
{[0.057]}\end{array}$ & $\begin{array}{l}-0.00187 \\
{[0.00327]}\end{array}$ \\
\hline \multicolumn{4}{|c|}{$\begin{array}{l}\text { Regional Characteristics (Northern } \\
\text { Uplands dummy omitted) }\end{array}$} \\
\hline Urban dummy & $\begin{array}{c}0.163 \\
{[0.026]^{* * *}}\end{array}$ & & \\
\hline Red River Delta & $\begin{array}{c}-0.307 \\
{[0.029]^{* * *}}\end{array}$ & $\begin{array}{c}-0.391 \\
{[0.029]^{* * *}}\end{array}$ & $\begin{array}{c}-0.88112 \\
{[0.15152]^{* * *}}\end{array}$ \\
\hline North Central Coast & $\begin{array}{c}-0.117 \\
{[0.031]^{* * *}}\end{array}$ & $\begin{array}{c}-0.16 \\
{[0.035]^{* * *}}\end{array}$ & $\begin{array}{c}-0.99916 \\
{[0.00302]^{* * *}}\end{array}$ \\
\hline South Central Coast & $\begin{array}{c}-0.265 \\
{[0.036]^{* * *}}\end{array}$ & $\begin{array}{c}-0.315 \\
{[0.036]^{* * *}}\end{array}$ & $\begin{array}{c}-0.96828 \\
{[0.06741]^{* * *}}\end{array}$ \\
\hline Central Highlands & $\begin{array}{c}0.143 \\
{[0.057]^{* *}}\end{array}$ & $\begin{array}{c}0.206 \\
{[0.080]^{* * *}}\end{array}$ & \\
\hline South East & $\begin{array}{c}-0.141 \\
{[0.046]^{* * *}}\end{array}$ & $\begin{array}{c}-0.118 \\
{[0.050]^{* *}}\end{array}$ & \\
\hline Mekong Delta & $\begin{array}{c}-0.347 \\
{[0.031]^{* * *}}\end{array}$ & $\begin{array}{c}-0.354 \\
{[0.031]^{* * *}}\end{array}$ & $\begin{array}{c}-0.98386 \\
{[0.03721]^{* * *}}\end{array}$ \\
\hline Observations & 3532 & 2887 & 530 \\
\hline Pseudo R2 & 0.2503 & 0.2064 & 0.521 \\
\hline
\end{tabular}

Notes: 1) The regression is presented in the marginal effect format. The coefficients reflect the marginal effect of changes in the respective independent variable. For dummy variables the marginal effect is for the discrete change of dummy variable from 0 to 1 .

2) Robust standard errors are in brackets

$3)^{*}$ significant at $10 \%$; ${ }^{* *}$ significant at $5 \%$; ${ }^{* * *}$ significant at $1 \%$

These results confirm most of our expectations. The poorer households in rural areas are more likely to be net buyers. In addition, larger households, households that are farming cash crops intensively, households that don't own land, and working outside the agriculture are also more likely to be net buyers. As expected the households that live in the two rice bowls of Vietnam (Red River Delta and Mekong River Delta) are less likely to be net buyers (more likely to be net sellers). On the other hand those living in Central Highlands have a higher chance of being buyers than the households with similar characteristics living in Northern Uplands (our base region). 


\section{SWITCHING}

We look at the households who switched from net buyers to net sellers between 1993 and 1998, and examine the characteristics and their effect on the probability of the switch. The significant number of households who switched (around 21\% of the population switched from one group to the other) prompts the question of the suitability of using net seller, net buyer groups in welfare predictions. The initial household characteristics and endowments are used to estimate the determinants of the switch. We group the households into two sub-samples according to their net selling position in 1993. For each subgroup we create the switch variable which is a dichotomous variable if the household has switched from its position in 1993. Thus we could estimate two Probit models (similar to equation 9 with the dependent variable being the switch dummy), to determine the characteristics of households who switched from net seller in 1993 to net buyer in 1998, or net buyer in 1993 to net seller in 1998. For each model staying in the same net selling position is the control group.

The more interesting case is the switch from net buyer to net seller, as it would show who extended (or ventured into) rice production from the subsistence (small) farmers and urban buyers. We present the results of that estimation in Table A.13 in the Annex. Everything else being equal, living in an urban area decreases the probability of the switch by 10\%, while living South Central Coast and Mekong Delta increases it (12\% and 8\% respectively) compared to living in the Northern Uplands. On the other hand, households that lived in Central Highlands and Southeast are less likely (7\% and 4\% respectively) to switch to net seller compared to their counterparts in Northern Uplands. Being a landless household decreases the probability of switching by $13 \%$ and also a marginal increase in share of cash crop profit in income decreases the probability by $7 \%$. Turning to the intensity of net-buying, we find that both marginal buyers and medium buyers are more likely to switch compared to large net-buyers (the increase in probability is $16 \%$ and $6 \%$ respectively). 
Table A.13. Switch from Buyer to Seller (PROBIT)

Dependent Variable switch from buyer to seller dummy=1 if buyer in 93 seller in 98 (=0 is buyer in both 93 and 98 )

All Buyer households in 1993

Demographics

Household size

$-0.002$

[0.003]

Gender of HH Head (1=male)

0.009

[0.015]

Age of $\mathrm{HH}$ Head

$-0.001$

[0.000]*

Highest Diploma Obtained by HH Head (No

diploma dummy is omitted)

Primary

0.009

[0.016]

Lower Secondary

$-0.019$

[0.016]

Upper Secondary

$-0.035$

[0.022]

Technical Worker

$-0.044$

$[0.018]^{* *}$

Vocational High

$-0.01$

[0.025]

Undergraduate

$-0.036$

[0.027]

Economic characteristics

Landless dummy (1= no land)

$-0.127$

Share of cash crop income

$[0.017]^{* * *}$

$-0.069$

[0.037]*

Share of non-ag wages

$-0.028$

[0.024]

Intensity of Net-Buy Dummy Large buyer dummy omitted)

Marginal buyer

0.156

Medium Buyer

$[0.029]^{* * *}$

0.054

$[0.020]^{* * *}$

Regional Characteristics (Northern Uplands

dummy omitted)

Urban dummy

$-0.094$

Red River Delta

[0.017]***

0.026

[0.020]

North Central Coast

$-0.006$

[0.019]

South Central Coast

0.122

$[0.033]^{* * *}$ 
All Buyer households in 1993

Central Highlands $-0.075$

South East

[0.013]***

$-0.039$

Mekong Delta

$[0.018]^{* *}$

0.081

$[0.028]^{* * *}$

Observations

2132

Pseudo R2

0.203

Notes: 1) The regression is presented in the marginal effect format. The coefficients reflect the marginal effect of changes in the respective independent variable. For dummy variables the marginal effect is for the discrete change of dummy variable from 0 to 1.

2) Robust standard errors are in brackets. 